\title{
An empirical thermal history of the Earth's upper mantle
}

\author{
Dallas Abbott, Lee Burgess, and John Longhi \\ Lamont-Doherty Earth Observatory, Palisades, New York
}

Walter H. F. Smith

NOAA Geosciences Laboratory, Silver Spring, Maryland

\begin{abstract}
We have compiled petrological and geochemical data from 71 ophiolite suites and greenstone belts, which range in age from 15 to $3760 \mathrm{Ma}$. We have selected those rocks whose compositions indicate that they are either normal mid-ocean ridge basalts (MORBs) or hotspot-type MORBs. Then we used the data base to calculate the most primitive liquidus temperature for each rock suite. The results show that the liquidus temperature of the Phanerozoic ophiolites ranges from a low of $1212^{\circ} \mathrm{C}$ to a high of $1417^{\circ} \mathrm{C}$. Using these data and two exponential curves bracketing the maximum and minimum temperatures versus time, we infer that the Phanerozoic suites had a mean liquidus temperature of $1272 \pm 7^{\circ} \mathrm{C}$ and a mean temperature range of $1218^{\circ}$ to $1425^{\circ} \mathrm{C}$. The liquidus temperatures of Archean MORBlike greenstones range from $1305^{\circ}$ to $1576^{\circ} \mathrm{C}$. Using these data and two exponential curves bracketing the maximum and minimum temperatures versus time, we infer that Archean melts at $2.8 \mathrm{Ga}$ had a mean liquidus temperature of $1399 \pm 13^{\circ} \mathrm{C}$ and a temperature range from $1301^{\circ}$ to $1533^{\circ} \mathrm{C}$. Using two different methods, we show that the change in the mean liquidus temperature since the late Archean is from $96 \pm 13^{\circ} \mathrm{C}$ (from temperature ranges) to $127 \pm 20^{\circ} \mathrm{C}$ (from temperature means). When we convert these liquidus temperatures to potential temperature of the mantle, we find that the change in the mean upper mantle potential temperature since the late Archean is from $137 \pm 8^{\circ} \mathrm{C}$ (from temperature ranges) to $187 \pm 42^{\circ} \mathrm{C}$ (from temperature means). This change is less than that which was previously thought to have occurred. We compared the liquidus temperatures calculated from our data set with an independent data set from the modern day Pacific plate. The resulting histograms have the same shape and the same temperature range, showing that our method for calculating mantle temperatures from MORBlike rocks in ophiolite suites is valid. When our calculated liquidus temperatures for all time intervals are plotted in histograms, the resulting distributions are not bimodal, but skewed unimodal. That is, the distributions show a high-T tail which results from the presence of hotspot magmas in the data set. The Archean temperature distribution is also skewed unimodal, and the high-temperature Archean rocks, such as komatiites, plot in the hotspot area of the distribution. This strongly supports the contention that komatiites do not represent "normal" Archean mantle but rather were probably erupted by hotspots. Our data suggest that the relative proportion of hotspot magmas in oceanic lithosphere has remained nearly constant over geologic time.
\end{abstract}

\section{Introduction}

The thermal history of the Earth has been a subject of interest and speculation since the mid-19th century. It is now generally accepted that the Earth has cooled slowly since its formation and that the heat generated in the interior of the Earth is the result of the radioactive decay of isotopes of $\mathrm{K}, \mathrm{U}$, and Th [Wasserburg et al., 1964]. However, the rate of cooling and the secular changes in the Earth related to that cooling are still debated.

Five processes control the flow of heat from the interior of the Earth: (1) radioactive heat production, (2) transport of heat across the core-mantle boundary, (3) heat transport by convection in the mantle, (4) crustal formation, and (5) the

Copyright 1994 by the American Geophysical Union.

Paper number 94JB00112.

$0148-0227 / 94 / 94 \mathrm{JB}-00112 \$ 05.00$ conductive cooling of the lithosphere. The first two processes add heat to the mantle, while the last two remove it. Any attempt to model the secular change of upper mantle temperature over the history of the Earth must incorporate the effects of all these processes.

Our understanding of the net effect of these processes varies considerably. Estimates of radioactive isotope concentrations in the mantle give relatively precise predictions of internal heating [Wasserburg et al., 1964], but estimates of the net cooling rate have a considerable range. Even with supercomputers, heat transport by convection is difficult to model, hence most models of mantle convection must incorporate simplifications and assumptions whose aggregate effects are difficult to fully understand. As a result, different authors have obtained widely different estimates of the potential temperature of the upper mantle in the Archean.

Based upon simple convection models and geological observations, Jarvis and Campbell [1983] argued that the average Archean mantle was no more than $100^{\circ} \mathrm{C}$ hotter than at 
present. More recently, based upon a model of mantle plumes and plume conduits, Campbell and Griffiths [1992] argue that the average Archean mantle was probably less than $50^{\circ} \mathrm{C}$ hotter than the present mantle. On the other hand, using simple convection models and geological observations, Sleep and Windley [1982] and McKenzie [1984] obtained much higher values for the average temperature of the Archean mantle, $200^{\circ}$ to $300^{\circ} \mathrm{C}$ hotter than at present. Nisbet and Fowler [1983] cite the abundant production of komatiites in the Archean as requiring a much hotter mantle, at least $300^{\circ} \mathrm{C}$ hotter than the present mantle.

Komatiites are extrusive ultramafic rocks which were erupted at temperatures in excess of $1400^{\circ}-1500^{\circ} \mathrm{C}$ [Arndt and Nisbet, 1982]. There is a secular decrease in the abundance of komatiites over time, and they have occurred only rarely in the Phanerozoic. An implicit assumption in many discussions of the origin of komatiitic melts has been that they represent the "average" mantle regime in the Archean, in other words, that they represent the dominant primitive magmatic composition in the Archean. However, prior to this work, no one has quantitatively evaluated the abundance of komatiitic primitive melts. As we discuss further on, there is the possibility that volcanic suites containing komatiites may have been preferentially preserved. Furthermore, because petrologists are very eager to study komatiitic suites, there may be a sampling bias in the petrologic studies.

In fact, komatiites in both the Archean and the Phanerozoic probably represent the upper end of a range of temperatures at which mantle melts are erupted. In the Phanerozoic, the most abundant mantle-derived melts erupt at spreading ridges. These "normal mid-ocean ridge basalts," e.g., MORB, represent the median temperature of the Phanerozoic mantle. The hightemperature part of the Phanerozoic distribution corresponds to hotspots. Although the terms "normal ridge" and "hotspot" may tempt one to think that the upper mantle temperature distribution is bimodal, we doubt that this is true. Instead, the rapid entraining of cooler upper mantle material into a hot, rising plume probably smears out the temperature distribution, so that hotspots correspond to the high-temperature tail of a skewed unimodal distribution.

It is possible that there has been a secular change in the relative amounts of ordinary and plume-type (i.e., hotspot) convection. Sleep et al. [1988] argued that the Archean had no hotspots because there were few identifiable hotspot tracks crossing Archean cratons. However, their analysis failed to consider the difficulty with which present day hotspots penetrate the thicker Archean age cratonic lithosphere. Because we know that some Archean cratons were already over $220 \mathrm{~km}$ thick in the Archean [Richardson et al., 1984], the Archean continental lithosphere provided a greater barrier to hotspots than more recently formed 100 to $150-\mathrm{km}$-thick continental lithosphere. Thus the absence of identifiable ageprogressive hotspot tracks on Archean cratons is not particularly surprising.

On the other hand, Campbell et al. [1989] argue that Archean komatiites must have been produced by hotspots based on the work of Kato et al. [1988a, 1988b], who have shown that certain trace element ratios would be nonchondritic if melting extended to the lower mantle. An average Archean mantle temperature of roughly $1500^{\circ}-1600^{\circ} \mathrm{C}$ would preclude the nearchondritic values of certain trace element ratios in the upper mantle [Campbell et al., 1989].

The overall range of mantle temperatures in the Archean would indicate whether hotspots existed more than $3.0 \mathrm{Ga}$ ago. The absence of hotspots would be consistent with a narrow $\left(<100^{\circ} \mathrm{C}\right)$ temperature range in the Archean. In the present day, if one looks at the temperature distribution of the mantle beneath mid-ocean ridges [Klein and Langmuir, 1987], a qualitative analysis shows that most of the data fall within a very narrow range of temperature (N-type MORB) while the remaining data (hotspots) skew the distribution towards higher temperatures. In this paper, we derive a more quantitative estimate of the temperature distribution in the Phanerozoic and the Archean mantle.

\section{Which Rocks Preserve A Record of Mantle Temperatures?}

MORBlike suites are generated by decompressive partial melting of the mantle in the absence of large quantities of water. These suites may include primitive lavas that record mantle temperatures. MORBlike rocks can be generated in four environments: mid-ocean ridges, back arc basins, primitive island arcs, and hotspots [Hawkins, 1980; Gill, 1984; Klein and Langmuir, 1987; Leeman et al., 1990]. Basalts that have been preserved on the continents, and which are associated with marine sediments, such as ophiolites and greenstones, might possibly be MORBlike and are candidates for this study. However, not all ophiolites and greenstones are MORBlike, and not all MORBlike suites preserve an accurate record of mantle temperatures.

The MORBlike suites we sought for our study have several characteristics. They are either alkaline (e.g., hotspot suites) or tholeiitic. MORBlike rocks have relatively high $\mathrm{TiO}_{2}$ contents, all greater than $0.4 \%$. The $\mathrm{Al}_{2} \mathrm{O}_{3}$ and $\mathrm{CaO}$ contents are above the values in a pyrolitic mantle, in contrast to nonMORB like rocks such as cumulates, boninites, and severely altered rocks. MORB-like rocks also have $\mathrm{SiO}_{2}$ contents that are less than those of boninites with the same $\mathrm{Mg}$ number [Rogers and Saunders, 1989]. We have only used samples with a tholeitic or alkaline composition. No calc-alkaline or boninitic rocks are used.

We gathered information from the literature, compiling chemical analyses of rocks believed to originate as partial melts of the mantle, and for which accurate geochronologic data exists. We carefully reviewed each rock description, discarding any data where the rock composition may have been severely contaminated or altered. In our suites, which do exhibit modest degrees of alteration, multiple analyses of the same rock produce temperature estimates which vary by 5 to $10^{\circ} \mathrm{C}$. These variations in the temperature estimate are indicative that modest alteration of the rock does not produce large errors in our estimate of the primitive liquidus temperature.

We identified MORBlike rock suites in our data base by examining the rare earth element (REE) patterns and trace element compositions. Normal MORBs generally have values of $\mathrm{REE}_{\mathrm{rock}} / \mathrm{REE}_{\text {chondrite }}$ in the range of 8 to 15 and the resulting patterns are usually light-REE depleted to flat [Coleman, 1977]. The chondrite-normalized [Anders and Grevesse, 1989] REE patterns of hotspot rocks have steep, nearly log-linear slopes and show considerable enrichment in light REE. Both of these REE patterns were considered acceptable. Unacceptable patterns include those with severe depletions in any element (less than 3-5 times chondritic) and those with patterns that were significantly different from those 
of normal MORB or hotspot rocks. We preferred suites where the trace element distribution patterns were either completely within the MORB field or distributed among both the withinplate basalt (hotspot) and MORB fields [Pearce and Cann, 1973; Pearce and Norry, 1979; Pearce et al., 1984].

Our goal was to obtain analyses of the most primitive rocks in each suite, those which represent the earliest partial melt of the mantle. The most primitive rock has undergone a minimum amount of crystal accumulation and fractionation prior to its eruption at the surface. We avoided rocks which have undergone crystal accumulation or fractionation. Cumulate rocks yield overestimates of the temperatures in the magma source region, whereas fractionated rocks yield underestimates.

In order to reduce the possibility of compositions affected by crystal accumulation, we looked for fine-grained rocks. We used analyses of flow tops, pillows, and diabases and did not use massive rocks, gabbros, and flow interiors. In komatiitic suites, we prefer rocks with microspinifex texture over those with macro-spinifex texture, since recent studies have suggested that macrospinifex textures form slowly enough to allow some crystal accumulation [Walker et al., 1988]. Microspinifex rocks are also less susceptible to alteration and are more homogeneous than macrospinifex rocks.

In order to identify cumulates, it has been traditional to use the $\mathrm{Cr}$ : $\mathrm{Ni}$ ratios. We found the $\mathrm{Cr}$ : $\mathrm{Ni}$ ratio helpful but not definitive. In suites with measured olivine compositions, komatiitic rocks with $\mathrm{Cr} / \mathrm{Ni}$ ratios in excess of 5 to 10 are usually cumulates. However, there are significant differences in the $\mathrm{Cr} / \mathrm{Ni}$ ratios derived from the same rock using different analytical techniques and $\mathrm{Cr}$ and $\mathrm{Ni}$ are mobile during hydrothermal alteration [Hoffman, 1984]. Thus the $\mathrm{Cr} / \mathrm{Ni}$ ratio must be used in concert with all other available data. Although changes in the shape of REE patterns can identify cumulates within basaltic suites, the REE element patterns of basaltic komatites and komatiites do not change shape during olivine accumulation. Thus cumulates in komatiitic suites can only be identified using REE if there are massive amounts of olivine accumulation.

A partial cumulate in a komatiitic suite can be identified using two criteria, total $\mathrm{TiO}_{2}$ content and the maximum forsterite (Fo) content of the olivine. Recent work on Archean komatiites suggests that all rocks with boninitic $\mathrm{TiO}_{2}$ contents $(<0.4 \%)$ are cumulates [Nisbet and Cheadle, 1992]. We also calculated the Fo content of the olivine in equilibrium with each rock of a suite, on the basis of that rock's bulk composition. The rock is assumed to be a cumulate if the calculated Fo value exceeds the maximum Fo value measured in that rock or in associated rocks.

Because a relatively small percentage of our suites have direct measurements of olivine composition, we sought to expand the number of suites with estimates of olivine composition. We found that in well-preserved suites with analyses of cumulates and of individual olivine grains, the composition of the most forsteritic olivine agreed well with an inferred forsterite content from the $\mathrm{Fe} / \mathrm{Mg}$ ratio of the cumulate rock with the lowest $\mathrm{Al}_{2} \mathrm{O}_{3}$. For example, in the Bay of Islands ophiolite, the maximum Fo content measured on olivine is 0.91 [Casey et al., 1985], and the Fo content of olivine inferred from the $\mathrm{Fe} / \mathrm{Mg}$ ratio of the most $\mathrm{Al}$-poor cumulate is also 0.91 . In suites with analyses of both $\mathrm{FeO}$ and $\mathrm{Fe}_{2} \mathrm{O}_{3}$, we obtained an upper limit for the Fo content of the olivine from the relation $\mathrm{Fe} 2+\sqrt{\mathrm{Fe}}=0.93$ [Christie et al., 1986]. The
$\mathrm{Fe} 2+/ \mathrm{Mg}$ ratio is a reasonable tool to estimate the Fo content of olivine in less altered suites but may overestimate the Fo content of more altered rocks. We found that less altered, low $\mathrm{Al}_{2} \mathrm{O}_{3}$ samples had more than $90 \%$ of their iron as $\mathrm{Fe} 2+$, thus samples with an $\mathrm{Fe}_{2} \mathrm{O}_{3} /\left(\mathrm{Fe}_{2} \mathrm{O}_{3}+\mathrm{FeO}\right)$ ratios of more than 0.1 were considered likely to have undergone oxidative alteration and were used with caution.

In using the composition of $\mathrm{Al}$-poor, $\mathrm{Mg}$-rich cumulates to infer the composition of the associated olivine, we had to avoid rocks which were residual peridotites. Residual perioditites usually have more forsteritic olivine than direct cumulates. Although it is possible to identify residual rocks using textural criteria in well-preserved suites, metamorphism obliterates most of the primary textural features. Fortunately, residual peridotites have very low $\mathrm{TiO}_{2}$ contents compared to primary cumulates. Furthermore, we looked at a number of suites with REE element analyses of residual and cumulate peridotites and found that residual rocks were readily identifiable because their REE contents were all or largely below chondritic abundances [Beccaluva et al., 1980; Dymek et al., 1988]. None of the residual peridotes had more than $0.1 \% \mathrm{TiO}_{2}$ and most had much less. Therefore any peridotite rock with a $\mathrm{TiO}_{2}$ content of less than $0.1 \%$ was considered residual and was not used to estimate the Fo content of olivine.

\section{Methods}

We use chemical analyses of rocks derived from the upper mantle, such as primitive magmas in ophiolites and greenstone belts, to calculate eruption temperatures. We then convert the calculated eruption temperatures to potential temperatures to construct an empirical curve for the cooling of the mantle over time. Rocks that originate as magmas formed by partial melting of upper mantle material can be used as paleo-thermometers because the melt compositions depend upon the upper mantle temperature at the time of their formation. If the magma is quickly extracted and solidified into rock (and if that rock is not subsequently too altered), then it preserves information about upper mantle temperature. Klein and Langmuir [1987] confirmed this temperature-composition dependence, by showing that the sodium content of fresh ridge-crest basaltic glass correlates with ridge crest elevation (which is assumed to be controlled by the combination of mantle temperature and lithospheric density structure).

\section{Measuring the Liquidus Temperature of Primitive Mantle Melts}

It is well-known that the ratio of iron to magnesium in a primitive basaltic magma is directly related to its liquidus temperature [Roeder and Emslie, 1970; Longhi et al., 1978]. Furthermore, the liquidus temperature of the basalt is equal to the temperature at the top of the convecting mantle, where that magma was last segregated. Although the mantle is not perfectly adiabatic, the mantle is thought to be close to adiabatic [Langmuir et al., 1992] which implies that the basalt liquidus temperature is directly related to the potential temperature of the upper mantle.

Our computer program to estimate low-pressure liquidus temperatures from rock composition uses a constant value of the $\mathrm{Fe}-\mathrm{Mg}$ exchange coefficient $\left(K_{D}=0.31\right)$ between olivine and liquid based on published and unpublished experimental data [e.g., Ulmer, 1989]. This allows $\mathrm{FeO}(\mathrm{ol}) / \mathrm{MgO}(\mathrm{ol})$ to be calculated from the liquid composition. Next, an estimate of 
the mol $\% \mathrm{Cr}_{2} \mathrm{O}_{3}, \mathrm{MnO}$, and $\mathrm{CaO}$ in olivine is made from the partition coefficients given by Longhi et al., [1978]. Then, absolute concentrations of $\mathrm{FeO}$ and $\mathrm{MgO}$ in olivine are obtained from a mass balance based on olivine stoichiometry, $(\mathrm{Mg}, \mathrm{Fe}, \mathrm{Mn}, \mathrm{Cr}, \mathrm{Ca})_{2} \mathrm{SiO} 4$, i.e., $66.67=\mathrm{FeO}+\mathrm{MgO}+\mathrm{MnO}+$ $\mathrm{CrO1.5}+\mathrm{CaO}$. Finally, temperature is calculated from equation $\mathrm{B} 2$ of Langmuir et al., [1992] $\left(\ln K_{d} \mathrm{Mg}=6921 / \mathrm{T}+\right.$ $0.034 \mathrm{Na}+0.063 \mathrm{~K}+0.01154 \mathrm{P}-3.27$ ), which relates temperature to $\mathrm{MgO}$ in olivine and $\mathrm{MgO}$ and alkalies in the liquid. This equation recovers data from mid-ocean ridge basalts with an average error of 5.3\% [Langmuir et al., 1992]. Our program uses the chemical distribution coefficients of Roeder and Emslie [1970], and so gives liquidus temperatures at atmospheric pressure. We should, more properly, correct for pressures corresponding to depths just below the bottom of the lithosphere, but these depths are unknown in most cases and are shallow in the case of spreading centers, where the correction is within the error of the calculations, so no correction is made.

Error estimates for liquidus temperatures are derived from the temperature difference between the highest temperature rock in a suite and the next closest rock. The rock used to define the error bars can either be a cumulate, which is generally higher in liquidus temperature, or a noncumulate, which is always lower in liquidus temperature. Because multiple chemical analyses of the same rock produce temperature estimates that vary by $5^{\circ}$ to $10^{\circ} \mathrm{C}$, we defined a minimum error of $\pm 5^{\circ} \mathrm{C}$. We did not include any suite in our final analysis with an error greater than $\pm 31^{\circ} \mathrm{C}$.

\section{Results}

Using the program we developed, we calculated the equilibrium liquidus temperature for each greenstone belt and ophiolite suite listed in Tables 1 and 2 (Figure 1). The highest liquidus temperature we obtained is $1576^{\circ} \mathrm{C}$ for a periodititic komatiite from the 3.5-Ga Barberton Greenstone Belt. The lowest liquidus temperature we obtained is $1212^{\circ} \mathrm{C}$, for a basalt from the Shionomisaki Ophiolite, 15.5 Ma old. Thus the range of our calculated liquidus temperatures over the past 3.5 $\mathrm{Ga}$ is $364^{\circ} \mathrm{C}$. When the rocks are divided into age categories for the Middle Archean, the Late Archean, and the Phanerozoic, the individual ranges are smaller. Table 3 shows the time intervals for each age category, and the mean age within each category of the rock samples used for this study, as well as the temperature range and the calculated mean temperature in each age category.

We calculated the temperature range of the liquidus in each age group using two methods. The first temperature range is a simple mean of all the temperatures from the suites in that age group. The second temperature range is more quantitative, because it takes into consideration the following facts: our data are from suites with different ages, the age groups have differing amounts of data, and the temperatures from the oldest suites change faster with time. To combat these sources of bias in our estimates of the mantle temperature range, we fit bounding curves to the upper and lower limits of the liquidus temperature versus time (Figure 1). These bounding curves approximate the radiogenic heat production curve of Wasserburg et al., [1964]. We used this curve because we believe that mantle temperatures are closely tied to radiogenic heat production throughout geologic time. The lower bounds for each time interval correspond to the lowest liquidus temperatures we found from our data set, while the upper bounds correspond to the highest liquidus temperatures.

The Phanerozoic part of our data set has a mean age of 302 Ma. As shown in Table 3, the lowest Phanerozoic ophiolite liquidus is $1212^{\circ} \mathrm{C}$ and the highest is $1417^{\circ} \mathrm{C}$, with a range of $205^{\circ} \mathrm{C}$. From the curves fit to the data, the lowest liquidus temperature at $0.3 \mathrm{Ga}$ is $1218^{\circ} \mathrm{C}$ and the highest temperature is $1425^{\circ} \mathrm{C}$, with a range of $207^{\circ} \mathrm{C}$. The lowest liquidus temperature we found for late Archean greenstones is $1305^{\circ} \mathrm{C}$, and the highest is $1514^{\circ} \mathrm{C}$, for a range of $209^{\circ} \mathrm{C}$. From the curves bounding the data, the lowest liquidus temperature at 2.8 $\mathrm{Ga}$ is $1301^{\circ} \mathrm{C}$ and the highest is $1533^{\circ} \mathrm{C}$, for a range of $232^{\circ} \mathrm{C}$. The lowest liquidus temperature we found for the middle Archean greenstones is $1309^{\circ} \mathrm{C}$, and the highest is $1576^{\circ} \mathrm{C}$, for a range of $267^{\circ} \mathrm{C}$. From the bounding curves, the lowest liquidus temperature at $3.3 \mathrm{Ga}$ is $1327^{\circ} \mathrm{C}$ and the highest is $1567^{\circ} \mathrm{C}$, for a range of $240^{\circ} \mathrm{C}$. For any given time in Earth's history, our data suggest that the average range of liquidus temperatures has been equal to $236 \pm 31^{\circ} \mathrm{C}$. This suggests that the nature of the distribution of liquidus temperatures has changed little over the past $3500 \mathrm{Ma}$.

The data in Table 3 also show that the average liquidus temperature has decreased over time, from $1437^{\circ} \mathrm{C}$ in the middle Archean, to $1399^{\circ} \mathrm{C}$ in the late Archean, to $1272^{\circ} \mathrm{C}$ in the Phanerozoic, for a mean change in liquidus temperature of $127 \pm 20^{\circ} \mathrm{C}$ from the late Archean to the Phanerozoic and $165 \pm 42{ }^{\circ} \mathrm{C}$ from the middle Archean to the Phanerozoic. An alternative way of estimating the decline in average liquidus temperature is to look at the mean change in the upper and lower temperatures calculated from the bounding curves. The changes in liquidus temperatures from the bounding curves are $96 \pm 13^{\circ} \mathrm{C}$ from the late Archean to the Phanerozoic and $126 \pm 17^{\circ} \mathrm{C}$ from the middle Archean to the Phanerozoic.

We also plotted temperature versus time for subsets of our data base, taking only those samples with analyses of REE compositions (listed in Table 1), and using only suites with olivine compositions, either directly measured or inferred from related rocks (see Table 1). Figure 2 shows a plot of liquidus temperature versus age, but only includes those data which had rare earth analyses. The shapes of the two distributions in Figures 1 and 2 are alike, indicating that the data are internally consistent. Figure 3 shows a similar plot, but the samples are those with olivine compositions or inferred olivine compositions. Once again, the distribution is clearly similar, suggesting that the temperatures from suites which lack olivine compositions are not significantly biased.

Figure 4 shows two histograms of liquidus temperature plotted against frequency of occurrence. Figure 4a shows the liquidus temperatures in the Phanerozoic, and Figure $4 \mathrm{~b}$ shows the liquidus temperatures in the Archean (combined middle and late Archean data sets). Each figure has three separate histograms for the minimum temperatures, the average temperatures, and the maximum temperatures. The deviations from the overall shape of the Phanerozoic distribution result from the inclusion of data from one or two MORBlike suites; that is, $4-8 \%$ of the data points. These deviations are within the calculated error limits of our data.

The most striking thing to note in these figures is the similarity of the shapes of all the histograms and, in particular, the similar distributions of both the Phanerozoic and the Archean data. The distributions are all clearly unimodal, with extended high-temperature tails. In each data set, most of the rocks fall into the midtemperature area of the 
Table 1. A List of the Greenstone Belts and Ophiolite Suites Used in Our Final Data Base, Along With Their Ages and the Highest Liquidus Temperature, $T_{1}$, Obtained From the Samples.

\begin{tabular}{|c|c|c|c|c|c|c|c|c|}
\hline Name & Age & $T_{1}$ & $T$-err & $N$ & REE? & Fo-Ol & Fo-cum & Sample \# \\
\hline ABITIBI & 2710 & 1495 & 8 & 28 & yes & yes & no & 5(flowtop) \\
\hline ALAWA & 600 & 1229 & 5 & 20 & no & no & no & 7 \\
\hline ANDAMAN & 63.25 & 1239 & 10 & 12 & yes & no & no & 4 \\
\hline ANGAY-JUR & 197.5 & 1243 & 6 & 12 & yes & no & no & $4722-1 \mathrm{a}$ \\
\hline ANGAY-TRIAS & 224 & 1217 & 5 & 25 & yes & no & no & $472-12$ \\
\hline ANSHAN & 2660 & 1514 & 12 & 24 & yes & no & no & PRC-7b \\
\hline ARAVALLI & 2550 & 1427 & 30 & 20 & yes & no & no & 2 \\
\hline BAER BASSIT & 219 & 1247 & 5 & 18 & yes & no & yes & 73104 \\
\hline BARBERTON & 3451 & 1576 & 10 & 50 & yes & yes & no & $331 / 78$ \\
\hline BAY OF ISLANDS & 485.7 & 1282 & 11 & 40 & yes & yes & no & $1061 \mathrm{~A}$ \\
\hline BAYKAL-VITIM & 1700 & 1335 & 11 & 24 & yes & yes & no & 66 \\
\hline BELINGWE & 2760 & 1466 & 13 & 34 & yes & yes & no & NG199 \\
\hline CAPE SMTTH & 1960 & 1478 & 5 & 38 & yes & yes & no & 30420 \\
\hline CHAMROUSSE & 497 & 1299 & 5 & 18 & yes & no & no & 8020 \\
\hline COCKBURN & 390.5 & 1296 & 5 & 11 & no & no & no & 57983 \\
\hline DIEMALS & 2723 & 1445 & 9 & 25 & yes & no & no & 63673 \\
\hline DUN MT. & 272 & 1268 & 16 & 10 & yes & no & yes & $\mathrm{d}$ (basalt) \\
\hline ELY & 2690 & 1327 & 14 & 56 & yes & no & yes & E-205 \\
\hline FANUJ MASKUTAN & 84.5 & 1307 & 9 & 11 & no & no & yes & 39 \\
\hline GILLET & 575 & 1256 & 10 & 16 & yes & no & no & 5439 \\
\hline GORGONA & 86 & 1417 & 14 & 15 & yes & yes & nc & 141 \\
\hline GULLFJELLET & 489 & 1252 & 21 & 10 & yes & no & no & $\mathrm{Ba9}$ \\
\hline HEATHCOTE & 555 & 1231 & 5 & 18 & yes & no & no & 26380 \\
\hline HIDROLINA & 2508 & 1353 & 9 & 12 & no & no & yes & $\mathrm{Hi} 230$ \\
\hline HOLENARSIPUR & 3050 & 1423 & 5 & 27 & yes & no & yes & 23 \\
\hline ILE DE GROIX & 460 & 1325 & 15 & 9 & yes & no & no & 2442 \\
\hline ISLA MARGARITA & 120 & 1299 & 13 & 30 & yes & no & no & IIIH \\
\hline ISUA & 3760 & 1393 & 13 & 12 & yes & yes & no & 119229 \\
\hline JORMUA & 1960 & 1300 & 31 & 9 & yes & no & no & 625 \\
\hline KAMBAJDA & 2702 & 1385 & 16 & 12 & yes & yes & no & 25 \\
\hline KOIKARY & 2935 & 1383 & 5 & 13 & no & no & yes & $1257-1$ \\
\hline KOLAR & $29 ; 30$ & 1451 & 6 & 35 & yes & no & no & $3(17-10)$ \\
\hline KUCHMO & 2610 & 1394 & 5 & 18 & no & no & yes & 12 \\
\hline LAWIERS & 2.650 & 1452 & 22 & 22 & yes & no & yes & 180 \\
\hline LEKA & 497 & 1267 & 7 & 16 & yes & yes & no & $78-35$ \\
\hline LEW'ISEAN & 2900 & 1347 & 5 & 11 & yes & no & yes & 91 \\
\hline LIGURIDES & 172 & 1319 & 20 & 23 & yes & no & yes & Li33 \\
\hline MAD RIVER & 500 & 1264 & 10 & 17 & yes & no & no & 5346 \\
\hline MAl_EIVE, & 3000 & 1420 & 30 & 12 & no & no & no & 207625 \\
\hline MEEKATHARA & 2579 & 1442 & 14 & 11 & no & no & no & 1 \\
\hline MINNESOTA & 3255 & 1395 & 9 & 13 & yes & no & no & M-14-16 \\
\hline NIANJDAN & 2150 & 1431 & 5 & 10 & no & no & no & $\mathrm{BF} 7$ \\
\hline OM.AIN & 90 & 1263 & 5 & 32 & yes & yes & no & OM5782 \\
\hline OTTAWA & 1960 & 1427 & 8 & 10 & yes & yes & no & BLS-60-79 \\
\hline PALAJA LAMBA & 2860 & 1309 & 6 & 29 & yes & no & yes & $4(414)$ \\
\hline PALOSELVINSKY & 2850 & 1357 & 5 & 20 & no & no & yes & 8 \\
\hline PHALUD & 1012 & 1383 & 22 & 16 & yes & no & no & $221-7$ \\
\hline PINDOS & 167 & 1281 & 6 & 12 & yes & no & yes & 3 \\
\hline SHUKSAN & 163.5 & 1256 & 9 & 12 & yes & no & no & A-572(2) \\
\hline SKALVAER & 458 & 1246 & 9 & 10 & yes & no & no & H5 \\
\hline STAVFJORDAN & 468 & 1236 & 6 & 25 & yes & no & no & 8719 \\
\hline QINGYUAN & 2830 & 1387 & 5 & 9 & yes & no & yes & 11 \\
\hline SARGUR & 3050 & 1309 & 5 & 14 & no & no & yes & 2 \\
\hline SARMIENTO & 141 & 1259 & 17 & 11 & yes & no & no & U166-2 \\
\hline SCHLOS-YUZNO & 2900 & 1305 & 15 & 22 & no & no & 110 & 2 \\
\hline SHIONOMISAKI & 15.5 & 1212 & 5 & 9 & yes & no & no & 3-MS-7 \\
\hline
\end{tabular}


Table 1. (continued)

\begin{tabular}{lrlllllll}
\hline Name & Age & $T_{1}$ & $T$-er & $N$ & REE? & Fo-Ol & Fo-cum & Sample \# \\
& & & & & & & & \\
\hline SUOMUSSALMI & 2650 & 1329 & 9 & 12 & yes & no & no & S100 \\
TAIWAN & 15 & 1308 & 9 & 12 & yes & yes & no & $112 B$ \\
TALGA-TALGA & 3500 & 1529 & 21 & 13 & yes & no & no & 34 C \\
TETLLA & 105 & 1240 & 13 & 10 & no & yes & no & 25771 \\
THOMPSON & 1883 & 1366 & 8 & 34 & yes & no & yes & $109(495)$ \\
TOKSHINSKY & 2900 & 1394 & 19 & 10 & no & no & yes & $10 / 41-1$ \\
TORTUGA & 140 & 1223 & 6 & 29 & yes & no & no & NT-22 \\
TRINITY & 452 & 1256 & 5 & 13 & yes & no & yes & $17130 A$ \\
TROODOS & 85 & 1305 & 12 & 9 & yes & yes & no & $244 A L$ \\
VETRENY-POAS & 2010 & 1422 & 5 & 49 & no & no & yes & $3552 a$ \\
VISNES:KARMOY & 485 & 1335 & 19 & 21 & yes & no & no & K50 \\
WATERBURY & 500 & 1250 & 3 & 14 & yes & no & no & 5218 \\
WFLLINGTON & 555 & 1255 & 9 & 14 & yes & no & no & 26348 \\
WOOLMIN & 444 & 1273 & 12 & 9 & no & no & no & 20 \\
XIGAZE & 110 & 1328 & 21 & 26 & no & yes & no & 15 \\
& & & & & & & &
\end{tabular}

$\mathrm{N}$ refers to the total number of good samples in the data set. Because a second sample was used for the temperature error estimate, a large number of samples is necessary to obtain a small error on the liquidus temperature. REE, Fo-O1 and Fo-cum refers to the presence (yes) or total absence (no) of such data. The sample numbers are those used in the original references for each rock suite (see Table 2).

plots, while the very high temperature rocks are much less abundant, giving the distribution a skewed appearance.

\section{Sources of Error and Sampling Bias}

In assembling our data base, we used rock compositions from both Phanerozoic ophiolite suites and Archean greenstone belts. However, Archean greenstones are not exactly like
Phanerozoic ophiolites. For example, sheeted dikes and ultramafic residual mantle rocks are rarely identified in Archean greenstone belts. Although some of these differences have been attributed to the hotter Archean mantle and its resulting thicker oceanic crust [Hoffman and Ranalli, 1988], it is not completely clear how these differences might result in preferential preservation, which would bias our results. One possible mechanism for such a bias is that areas of the very thickest (i.e., 22-30 km) crust, corresponding to hotspot type

Table 2. Table of References Used to Compile the Data Listed in Table 1

\begin{tabular}{|c|c|}
\hline Name & References With Geochemical Data \\
\hline ABITIBI & $\begin{array}{l}\text { Ludden et al. }[1986], \text { Arndt et al. [1977], Arndt [1977], Barnes et al. [1983], } \\
\text { Cattell and Arndt [1987] }\end{array}$ \\
\hline ALAWA & Elueze $[1985]$ \\
\hline ANDAMAN & Ray et al. [1988] \\
\hline ANGAY-JUR & Pallister et al. [1989] \\
\hline ANGAY-TRIAS & Pallister et al. [1989] \\
\hline ANSHAN & Jahn and E:nst [1990], Zhai et al. [1990] \\
\hline ARAVALLI & Tremblay et al. [1989] \\
\hline BAER BASSIT & Parrot [1977] \\
\hline BARBERTON & $\begin{array}{l}\text { Smith et al. [1984], Hoffman [1984], Sun and Nesbitt [1978], Kroner and Todt } \\
\text { [1988], Viljoen and Viljoen [1969], Condie et al. [1977] }\end{array}$ \\
\hline BAY OF ISLANDS & Casey et al. [1985], Suen et al. [1979], Danning and Krogh [1985] \\
\hline BAYKAL-VITIM & Dobrzhinestakaya [1986], Konnikov [1991] \\
\hline BELINGWE & Sun and Nesbitt [1978], Nisbet et al. [1977] Nisbet et al. [1987] \\
\hline CAPE SMITH & $\begin{array}{l}\text { Moore [1977], Baragar and Scoates [1987], Francis and Hynes [1979], } \\
\text { Francis et al. [1981], Scott et al. [1988] }\end{array}$ \\
\hline CHAMROUSSE & Bodinier et al. $[1981]$ \\
\hline COCKBURN & Cawood [1984] \\
\hline DIEMALS & Nesbitt et al. [1984] \\
\hline DUN MT. & Davis et al. [1980] \\
\hline ELY & $\begin{array}{l}\text { Schulz [1982], Green and Schulz [1977], Sims and Morey [1972], Schulz } \\
\text { [1977] }\end{array}$ \\
\hline
\end{tabular}


Table 2. (continued)

\begin{tabular}{|c|c|}
\hline Name & References With Geochemical Data \\
\hline FANUJ MASKUTAN & Desmons and Beccaluva [1983] \\
\hline GLLET & Coish et al. [1985] \\
\hline GORGONA & Aitken and Echeverria [1984], Echeverria [1980] \\
\hline GULLFJELLET & Furnes et al. [1982] \\
\hline HEATHCOTE & Crawford and Keays [1987] \\
\hline HIDROLINA & Rivalenti et al. [1989], Rivalenti (written communication, 1990) \\
\hline HOLENARSIPUR & Drury [1982], Hussain and Naqvi [1983], Hussian et al. [1982] \\
\hline IIE DE GROIX & Bernard Griffiths et al. [1986] \\
\hline ISLAA MARGARITA & Mottana et al. [1985] \\
\hline ISUA & $\begin{array}{l}\text { McGregor and Mason [197\%], Allart [1976], Sun and Nesbitt [1978] } \\
\text { Dymek et al. }[1988], \text { Nutman [1986], Michard-Vitrac et al. }[1977]\end{array}$ \\
\hline JORMUA & Kontinen [1987] \\
\hline KAMBALDA & Sun and Nesbitt [1978], Arndt and Jenner [1986] \\
\hline KOIKARY & Rybakov and Svetova [1981a], Bogatikov [1988] \\
\hline KOLAR & Rajamani et al. [1985] \\
\hline KUCHMO & Jahn et al. [1980], Hanski [1980] \\
\hline LAWLERS & Sun and Nesbitt [1978], Naldrett and Turner [1977], Barnes et al. [1988] \\
\hline LEKA & Prestvik [1980], Furnes et al. [1988], Dunning and Pedersen [1988] \\
\hline LEWISIAN & Sills et al. [1982], O'Hara $\left.{ }_{\mathrm{i}} 1961\right]$ \\
\hline LIGUKIDES & Ottonello et al. [1984] \\
\hline MAD RIVER & Coish et al. [1986] \\
\hline MALENE, & Friend et al. [1981], Hall [1980b] \\
\hline MEEKATHARA & Hallberg et al. [1976] \\
\hline MINNESOTA & Wooden et al. [1980], Goldich et al. [1980], Schulz [1982] \\
\hline NIANDAN & Tegyey and Johan [1989] \\
\hline OMAN & Lippard et al. [1986] \\
\hline OTГAWA & Arndi et al. [1987], Baragar and Scoates [1987] \\
\hline PALAJA LAMBA & Lobach-Zuchenko et al. [1978] \\
\hline PALOSEL VINSKOI & Rybakov and Svetova [i981b], Bogatikov [1988] \\
\hline PHALUD & Volpe and MacDougall [1990] \\
\hline PINDOS & Capedri et al.[1980], Montigny et al. [1973] \\
\hline QINGYUAN & Zhai et al. [1985] \\
\hline SARGUR & Venkataramana et al. [1982] \\
\hline SARMIENTO & Stern $[1980]$ \\
\hline SCHILOS-YUZNO & Sokolov [1981] \\
\hline SHIONOMISAKI & Miyake [1985] \\
\hline SHUKSAN & Dungan et al. [1983] \\
\hline SKALVAER & Furnes et al. [1982] \\
\hline STAVFJORDAN & Furnes et al. [1982], Skjerlie et al. [1989] \\
\hline SUOMUSSALMI & Jalin et al. [1980], Mutanen [1976], Vidal et al. [1980] \\
\hline TAIWAN & Suppe et al. [1981], Jahn [1986] \\
\hline TALGA-TALGA & Gruitu et al. [1937] \\
\hline TETILLA & Spaded el al. [1987] \\
\hline THOMPSON & $\begin{array}{l}\text { Peredery [1979], Halden [1991], Baragar and Scoates [1987], Paktunc [1984], } \\
\text { Heamian tt al. [1986] }\end{array}$ \\
\hline TOKSHINSKY & Kulikov et al. [1981a], Bogatikov [1988] \\
\hline TORTUGA & Elthon and Ridley [1980], Stern [1980] \\
\hline TRINITY & Browxel and LaPierre [1983] \\
\hline TROODOS & $\begin{array}{l}\text { Rautenschlein et al. [1985], Smewing and Potts [1976], } \\
\text { Flower and Levine [1987] }\end{array}$ \\
\hline VETRENY-POAS & Kulikova and Kulikov [1981], Bogatikov [1988] \\
\hline VISNES:KAPMOY & Sturt et al. [1984] \\
\hline WATERBUP.Y & Coish et al. [1986] \\
\hline WELLINGTON & Crawford and Keays [1987] \\
\hline WOOLMIN & Cawood [1984] \\
\hline XIGAZE & Girardeau et al. [1985], Hanruo and Wanming [1980] \\
\hline
\end{tabular}




\section{ALL MORB-LIKE SUITES}

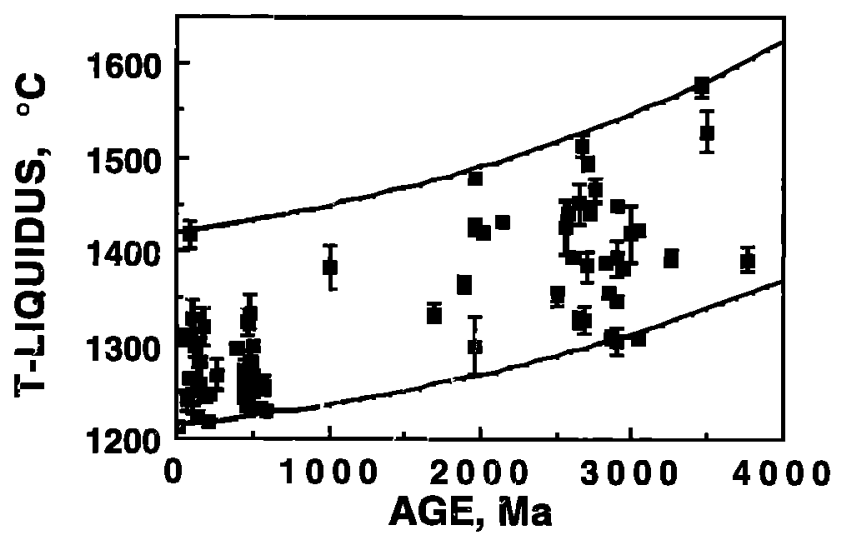

Figure 1. The primitive liquidus temperatures for each rock suite versus their ages, for all MORBlike suites used in this study. Exponential curves which approximate the shape of the radiogenic heat production curve of Wasserburg et al., [1964] mark the upper and lower boundaries of the data set.

temperatures, are essentially unsubductable. The buoyancy of the very depleted mantle beneath them causes polarity reversals of subduction zones, as has happened most recently at the Ontong Java plateau [Kroenke et al., 1991], leaving the thick crust unsubducted. Thus Archean greenstone belts formed at hotspots would be preferentially preserved.

This effect would tend to bias middle Archean liquidus temperatures, which are the hottest, to even higher values. If this bias is significant, we should interpret our middle. Archean-Phanerozoic temperature difference as the maximum possible value. On the other hand, our data indicate that this difference is relatively modest, only $126^{\circ}-155^{\circ} \mathrm{C}$ (Table 3 ). This argues against a large bias. Unfortunately, we cannot address this issue further without a more complete data set from Proterozoic MORBlike suites, data which are not available at present.

Another possible problem is a bias of petrologic studies. Ever since their discovery, petrologists have been fascinated by komatiites and have vied to find the highest temperature suites. Greenstone belts which lack komatiites or basaltic komatiites (and which correspond to cooler temperatures) have received relatively little attention. The peak in the Archean temperature histogram, at $1395^{\circ} \mathrm{C}$, which lies just above the temperature transition between a most primitive sample of basaltic composition and a most primitive sample of basaltic komatiite composition, might be indicative of a small bias of this type. Future petrologic work needs to be more evenly distributed among all Archean greenstone belts with MORBlike suites, regardless of whether or not komatiites are present.

\section{Comparison With Estimates of Temperature Derived From The Pacific Plate}

In order to check the overall validity of our technique and compare our results with those of others, we looked at the data of Klein and Langmuir [1987]. They inferred that the mantle

Table 3. Compilation of the Mean Temperature Data Derived From the Rocks in Table 1 According to Their Age

\begin{tabular}{|c|c|c|c|c|c|}
\hline Name & $\begin{array}{l}\text { Time Interval, } \\
\text { m.y. }\end{array}$ & $\begin{array}{c}\text { Mean Age, } \\
\text { m.y. }\end{array}$ & $\begin{array}{l}\text { Mean } T_{1} \text {, } \\
{ }^{\circ} \mathrm{C}\end{array}$ & $\begin{array}{l}T_{1} \text { Range } \\
\text { From Rocks, } \\
{ }^{\circ} \mathrm{C}\end{array}$ & $\begin{array}{l}T_{1} \text { Range } \\
\text { From Curves, } \\
{ }^{\circ} \mathrm{C}\end{array}$ \\
\hline $\begin{array}{l}\text { Phanerozoic } \\
\text { Late Archean } \\
\text { Middle Archean }\end{array}$ & $\begin{array}{l}0-600 \\
2400-3000 \\
>3000\end{array}$ & $\begin{array}{l}302 \pm 33 \\
2756 \pm 28 \\
3344 \pm 114\end{array}$ & $\begin{array}{l}1272 \pm 7 \\
1399 \pm 13 \\
1437 \pm 40\end{array}$ & $\begin{array}{l}1212-1417 \\
1305-1514 \\
1309-1576\end{array}$ & $\begin{array}{l}1218-1425 \\
1301-1533 \\
1327-1567\end{array}$ \\
\hline Name & $\begin{array}{l}\text { Time Interval, } \\
\text { m.y. }\end{array}$ & $\begin{array}{l}\text { Mean Age, } \\
\text { m.y. }\end{array}$ & $\begin{array}{l}\text { Mean } T_{p} \text {, } \\
{ }^{\circ} \mathrm{C}\end{array}$ & $\begin{array}{l}T_{p} \text { Range, } \\
\text { From Rocks, } \\
{ }^{\circ} \mathrm{C}\end{array}$ & $\begin{array}{l}T_{p} \text { Range } \\
\text { From Curves, } \\
{ }^{\circ} \mathrm{C}\end{array}$ \\
\hline $\begin{array}{l}\text { Phanerozoic } \\
\text { Late Archean } \\
\text { Middle Archean }\end{array}$ & $\begin{array}{l}0-600 \\
2400-3000 \\
>3090\end{array}$ & $\begin{array}{l}302 \pm 33 \\
2756 \pm 28 \\
3344 \pm 114\end{array}$ & $\begin{array}{l}1380 \pm 10 \\
1567 \pm 18 \\
1618 \pm 55\end{array}$ & $\begin{array}{l}1286-1594 \\
1432-1726 \\
1437-1804\end{array}$ & $\begin{array}{l}1297-1606 \\
1425-1750 \\
1464-1792\end{array}$ \\
\hline
\end{tabular}

The rock samples were divided into the three time intervals listed and a mean age was calculated for each tim.e interval. The table also shows the high and low temperatures derived from fitting two exponential curves which bracketted the highest and lowest liquidus temperatures versus time. The top table shows results in teirns of primitive liquidus temperatures $T_{1}$, and the bottom table shows results in terms of potential temperatures, $T_{p}$. 


\section{ALL SUITES WITH REE DATA}

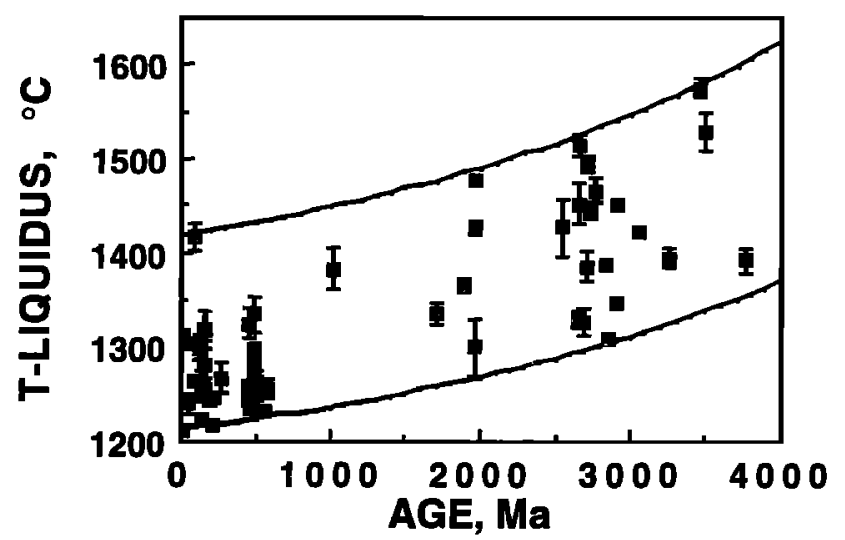

Figure 2. The primitive liquidus temperatures for all suites which include REE analyses plotted versus their ages. Boundary curves are the same as in Figure 1. The similarity in the distributions of data indicate that the data are generally consistent.

had a temperature range of $250^{\circ} \mathrm{C}$, based on their study of fresh, basaltic ridge crest glasses. The Phanerozoic liquidus temperatures from MORBlike ophiolite suites which we have calculated range from $1212^{\circ} \mathrm{C}$ to $1417^{\circ} \mathrm{C}$, a range of $205^{\circ} \mathrm{C}$, less than that of Klein and Langmuir [1987]. There may be two reasons for this difference. One is that we have relatively few Phanerozoic data sets (36 in all). The second is that our primitive liquidus temperatures are not the same as the potential temperature of the upper mantle. Because of the beat of melting, the potential temperature of the upper mantle is higher than the primitive liquidus temperature of the melt at the surface.

In order to test our technique, we convert our primitive liquidus temperatures to potential temperatures using the empirical relationship $\mathrm{Tp}=-1382.5+2.8046 \mathrm{~T}_{1}$ $-0.00049671\left(\mathrm{~T}_{1}\right)^{2}$ [McKenzie and Bickle, 1988; M. Bickle, personal communication, 1993] (Figure 5), and then compare them to the potential temperature range derived from our ophiolite suite. The potential temperatures derived from the liquidus temperatures of Phanerozoic ophiolite suites range from $1286^{\circ} \mathrm{C}$ to $1594^{\circ} \mathrm{C}$, a range of $308^{\circ} \mathrm{C}$. However, the maximum temperature from the Phanerozoic ophiolites is derived from Gorgona island, which is thought to be extremely unusual. A more representative Phanerozoic temperature range is derived from the $1.4 \%$ and $98.6 \%$ levels $(1 / 36=2.8 \%)$ of potential temperatures calculated from the distribution of residual depth anomalies on the Pacific plate (over 50,000 samples in half degree square areas)[Smith, 1990]. From temperatures derived from the Pacific plate, the potential temperature range in the Phanerozoic mantle is $270^{\circ} \mathrm{C}$, quite comparable to the $250^{\circ} \mathrm{C}$ range derived by Klein and Langmuir [1987].

\section{Mantle Temperature, Crustal Thickness, and Residual Depth Anomalies}

The melting column models of Klein and Langmuir [1987] and McKenzie and Bickle [1988] show that both the thickness of the oceanic crust and the thickness of the depleted portion of the mantle correlates with mantle potential temperature, as shown in Figure 6. Because the densities of both the crust and the depleted mantle differ from normal mantle, we can calculate their elevation if we assume that they are in isostatic equilibrium with normal mantle. Furthermore, it can be shown that residual depth anomalies, i.e., the actual depth minus the predicted depth at the top of conductively cooled oceanic crust of normal thickness -- are related to crustal thickness and therefore also to mantle potential temperature.

As an independent test of our Phanerozoic results, we decided to use geophysical data on residual depth anomalies from the Pacific Plate. First, we used the isostatic model (but not the densities) of Schubert and Sandwell [1989] to convert residual depth anomalies from the Pacific plate [Smith, 1990] to estimates of crustal thickness. Then, we used the model of McKenzie and Bickle [1988] to relate crustal thickness to mantle potential temperature. As a check on our methodology, we compared crustal thicknesses calculated from REE inversion on geochemical samples of Pacific basement to crustal thicknesses calculated from residual depth anomalies and found that they were quite comparable. For example, the crustal thickness calculated from REE inversion for the Ontong Java Plateau (site 807) is $18.7 \mathrm{~km}$ [White et al., 1992]. This is

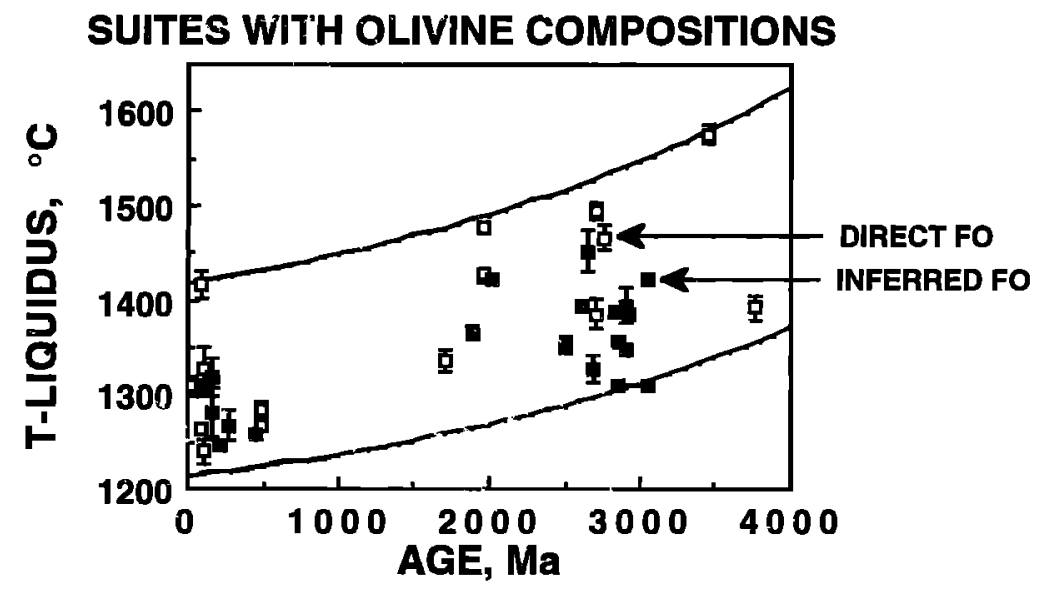

Figure 3. Primitive liquidus temperatures plotted versus age for those MORBlike suites with either directly measured olivine compositions (open squares) or inferred olivine compositions (solid squares). See text for a discussion of the method for inferring liquidus olivine compositions. Boundary curves are the same as in Figure 1. Again, note that the distribution of temperatures is similar to those in Figures 1 and 2. 

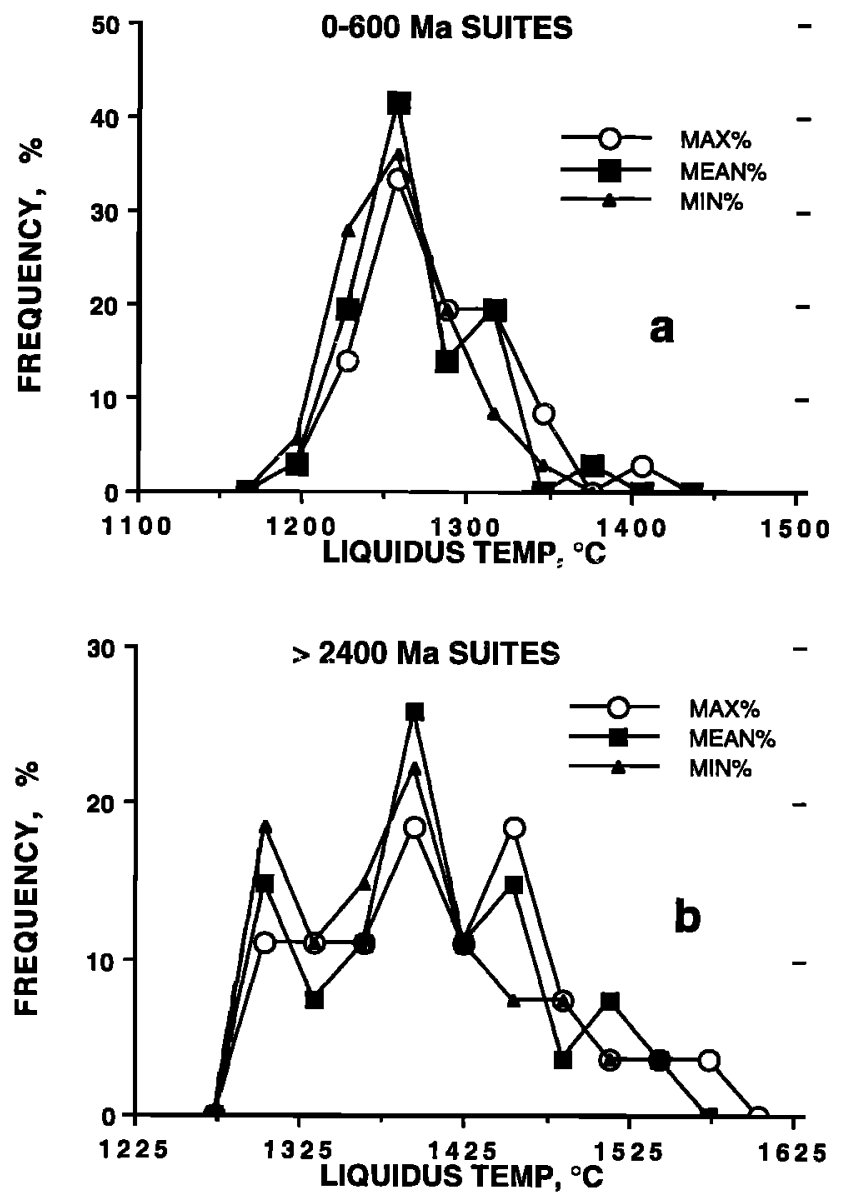

Figure 4. (a) Graph of the liquidus temperatures obtained for the Phanerozoic (0-600 Ma). (b) Graph of the liquidus temperatures obtained for the Archean ( $2400 \mathrm{Ma}$ to $3800 \mathrm{Ma}$ ). Data for both figures obtained using the methods outlined in text. Three percentage areas are shown: MIN, MEAN, and MAX. The shapes of the two distributions are very similar, i.e., both are unimodal, skewed distributions. This indicates that the relative proportion of hotspot volcanism has not changed much over geologic time.

quite comparable to the crustal thickness derived from the residual depth anomaly: $18.9 \mathrm{~km}$.

The Airy theory of isostasy requires that the thickness of the mantle root $(R)$ is directly related to the residual depth anomaly (H); that is,

$$
R\left(p_{m}-p_{c}\right)=H\left(p_{c}-p_{w}\right)
$$

where $p_{m}$ is the density of the mantle, $3.37 \mathrm{Mg} / \mathrm{m}^{3} ; p_{w}$ is the density of water, $1.028 \mathrm{Mg} / \mathrm{m3}$; and $\mathrm{p}_{\mathrm{c}}$ is the density of the crust, $2.86 \mathrm{Mg} / \mathrm{m} 3$ [Anderson, 1989; Defant, 1961]. As shown in Figure 7, the mantle root $(R)$ is almost 4 times as thick as the depth anomaly $(H)$. The excess crustal thickness, delta $t$ is the sum of $H$ and $R$. The excess crustal thickness for a given residual depth anomaly $\mathrm{H}$ is

$$
\begin{aligned}
\text { delta } t= & H+R=H+H\left(p_{c}-p_{w}\right) /\left(p_{m}-p_{c}\right)= \\
& H\left[1+\left(p_{c}-p_{w}\right) /\left(p_{m}-p_{c}\right)\right] .
\end{aligned}
$$

Calculations show that for every extra kilometer of oceanic crustal thickness, there is $218 \mathrm{~m}$ of residual depth anomaly. Normal crust is assumed to have a thickness of $7.1 \mathrm{~km}$ [White et al., 1992]. Therefore, the total crustal thickness $t_{c}$ in kilometers is

where $H$ is in meters.

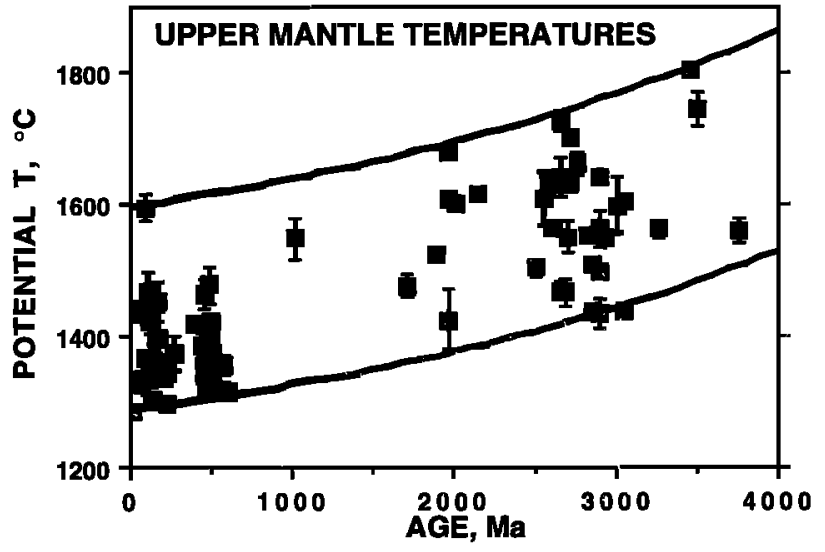

Figure 5. The potential temperatures for each rock suite versus their ages, for all MORBlike suites used in this study. Exponential curves which approximate the shape of the radiogenic heat production curve of Wasserburg et al., [1964] mark the upper and lower boundaries of the data set.

The next step is to convert the total crustal thickness $\left(t_{c}\right)$ to potential temperature $\left(T_{p}\right)$. We used an empirical relationship fit to the data of McKenzie and Bickle [1988]:

$$
\mathrm{T}_{\mathrm{p}}=1177.3+38.080\left(\ln \mathrm{t}_{\mathrm{c}}\right)+3.4131\left(\ln \mathrm{t}_{\mathrm{c}}\right)^{2}+6.0121
$$

This empirical equation fits the data on temperature and crustal thickness to a precision of better than $8^{\circ} \mathrm{C}$. The empirical equation gives a mantle potential temperature of $1310^{\circ} \mathrm{C}$ at $\mathrm{t}=$ $7.1 \mathrm{~km}$ and $\mathrm{H}=0$, which is well within the error of McKenzie and Bickle's estimate of a mantle potential temperature of $1280^{\circ} \mathrm{C}$ at a crustal thickness of $7 \mathrm{~km}$.

\section{Testing With Data From the Pacific Plate}

All of the oceanic crust of the Pacific plate was formed within the last $200 \mathrm{Ma}$. The distribution of basement ages on the Pacific plate suggests that the subduction process is random. That is, the probability of subducting any one piece of oceanic crust at any given time is independent of crustal age [Parsons, 1982]. Therefore the remaining oceanic lithosphere can be regarded as providing a random sample of mantle melts from the late Phanerozoic. Thus we can use the data on residual depth anomalies to independently verify the Phanerozoic

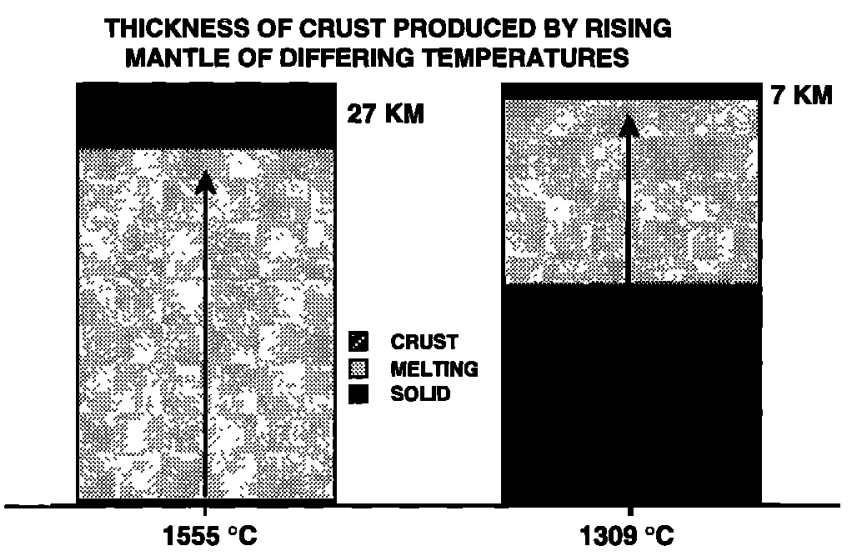

Figure 6. Illustration of melting column model. Hotter mantle begins to melt at a greater depth and produces thicker oceanic crust. Colder mantle begins to melt at lower depths and produces thinner oceanic crust. 


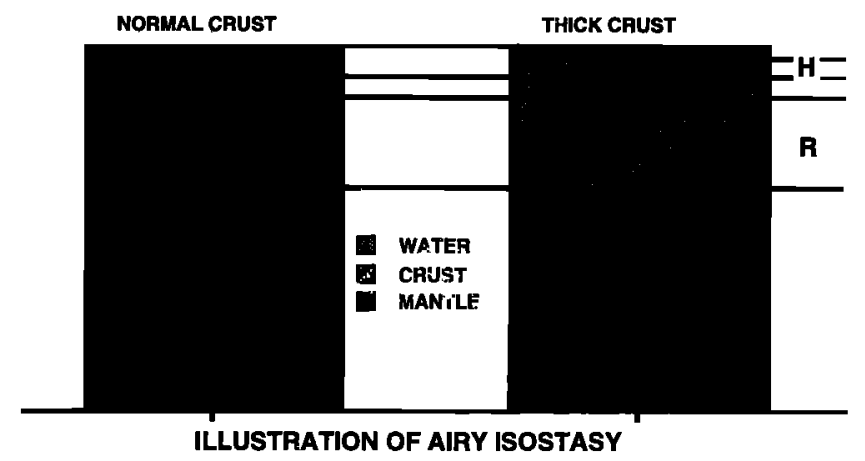

Figure 7. An illustration of Airy-type isostatic balance. Airy isostasy requires that thicker crust is compensated by a mantle root with a thickness which is directly proportional to the size of the residual depth anomaly.

temperature range that we derive from the ophiolite liquidus temperatures.

We used Smith's [1990] Pacific age-depth curve to estimate residual depth anomalies. Smith's curve is fit to ship soundings which were checked for quality using a crossover error analysis [Smith, 1993]. The curve is based on data distributed throughout the Pacific plate and fit to median, as opposed to mean, depths. We calculated the residual depth, $\mathrm{H}$, in each $1 / 2$ degree square within the Pacific plate and obtained a histogram of residual depth values. The histogram was then converted from residual depths into potential temperature using the above equations and the result is shown in Figure 8b.

The upper mantle temperatures derived from off-ridge hotspot volcanism tend to be overestimated, due to the fact that the new hotspot crust is not distinguished from the older crust it is built upon. Therefore we assume a $40^{\circ} \mathrm{C}$ error in each of the temperature calculations, which is roughly equivalent to an excess crustal thickness of $7 \mathrm{~km}$. Because of the term $\ln t_{c}$ in the equation for potential temperature from crustal thickness, the actual error is somewhat lower for the highest temperature rocks

A $40{ }^{\circ} \mathrm{C}$ value may be also an overestimate of the error because the age-depth curve of Smith [1990] produces far fewer positive residual depth anomalies than other curves. For example, the area of the South Pacific near French Polynesia is anomalously shallow with respect to the Parsons and Sclater [1977] curve; this shallowing has been called a "superswell" by McNutt and Judge [1990]. Smith [1990] showed that most of the Pacific plate seafloor less than $40 \mathrm{~m}$.y. of age is in the South Pacific. Because Smith's curve is fit to medians of samples equally distributed in area (a "majority-rule" approach), the superswell area defines the young age behavior of Smith's curve.

Thus the superswell area shows residual depths near zero (potential temperatures near $1310^{\circ} \mathrm{C}$ ) when Smith's curve is used. In contrast, the Parsons and Sclater [1977] curve was fit to a limited number of data selected from particular sites in the North Pacific and predicts deeper values than are seen in the South Pacific. By using Smith's curve, we make the implicit assumption that superswell depths are normal; if one uses the Parsons and Sclater curve then the superswell depths imply a large area of hotter temperature, as McNutt and Judge [1990] suggested. In fact, however, there is no evidence for a hotter region in the heat flow data from this area [Stein and Abbott, 1991].
Smith's median depth approach has other consequences for the shape of the histogram. Because the median depth curve estimates where the majority of depths fall at a given age, it minimizes the number of histogram counts which lie far from the curve. Thus the fatness of the tails of the histogram is less than it would be if we used some other curve fitting procedure. For example, a least squares fit minimizes the extreme values at the ends of the tails, rather than their fatness. Therefore the median depth approach is conservative in estimating the residual depth histogram.

In attributing all residual depths to variations in crustal thickness, and then potential temperature, we are ignoring the possibility that some residual depths are produced by pressure gradients in the asthenosphere (e.g. hotspot swells) [Smith and Morgan, 1992] and are not indicative of crustal thickness. However, Smith's [1990] map of residual depths shows that active hotspot swells are few, and their $H$ values are of smaller map area and magnitude than the plateaus (Ontong Java, Manihiki, etc.). Thus it is the plateaus that contribute the most structure to the histogram. The plateaus were primarily generated at spreading centers [Mahoney et al., 1993] and are areas of thick crust in isostatic equilibrium [Schubert and Sandwell, 1989]. The remaining positive anomalies are mostly associated with hotspot-generated ridge pairs (Cocos, Nazca) which formed at spreading centers. Therefore our assumptions about going from the residual depth anomaly $(\mathrm{H})$ to potential temperature $\left(T_{p}\right)$ are valid for most oceanic plateaus and hotspot tracks.

In order to compare our results from the inversion of residual depth anomalies on the Pacific plate to our results from Phanerozoic ophiolites, it is necessary to convert our residual depth anomaly results from estimates of crustal thickness, $t_{c}$, to estimates of primitive liquidus temperature, $T_{1}$. To do this, we use the following empirical equation [McKenzie and Bickle, 1988; M. Bickle, personal communication, 1993]:

$$
\begin{gathered}
T_{1}=1147.1+23.685\left(\ln t_{c}\right)-2.0338\left(\operatorname{ln~} t_{c}\right)^{2}+5.2411 \\
\left(\operatorname{ln~} t_{c}\right)^{3} .
\end{gathered}
$$

Figure 8 is a comparison of liquidus temperatures derived from the modern Pacific plate with those derived from the Phanerozoic ophiolites in our data set. As can be seen in Figure 8, the shapes of the two distributions are very similar, with most of the temperatures clustered over a $100^{\circ} \mathrm{C}$ range. Each distribution has a high-temperature tail which extends to over $1400^{\circ} \mathrm{C}$; in other words, each shows the skewed unimodal distribution which we described earlier in the paper. In addition, there is very good agreement between the two sets of liquidus temperatures. The distribution of temperatures for the modern Pacific plate is aways within $40^{\circ} \mathrm{C}$ of the calculated potential temperatures derived from the Phanerozoic MORBlike suites in our data base.

We argue that the slightly higher average temperatures (on average $32^{\circ} \mathrm{C}$ higher) derived from the Phanerozoic ophiolites are not significant given our present degree of resolution on geothermometers $( \pm 5 \%)$, the differences in time range of the data, and probable differences in spreading rate distribution of the data. Because half of the surface area of the Pacific plate is 0-60 m.y. old crust, the liquidus temperatures from the Pacific plate are most representative of the time interval 0-60 m.y. B.P. rather than 0-180 m.y. B.P. The Phanerozoic ophiolites represent the time interval from $0-600 \mathrm{~m}$.y. B.P. and on that basis alone would be expected to give an average temperature about $7^{\circ} \mathrm{C}$ higher. 

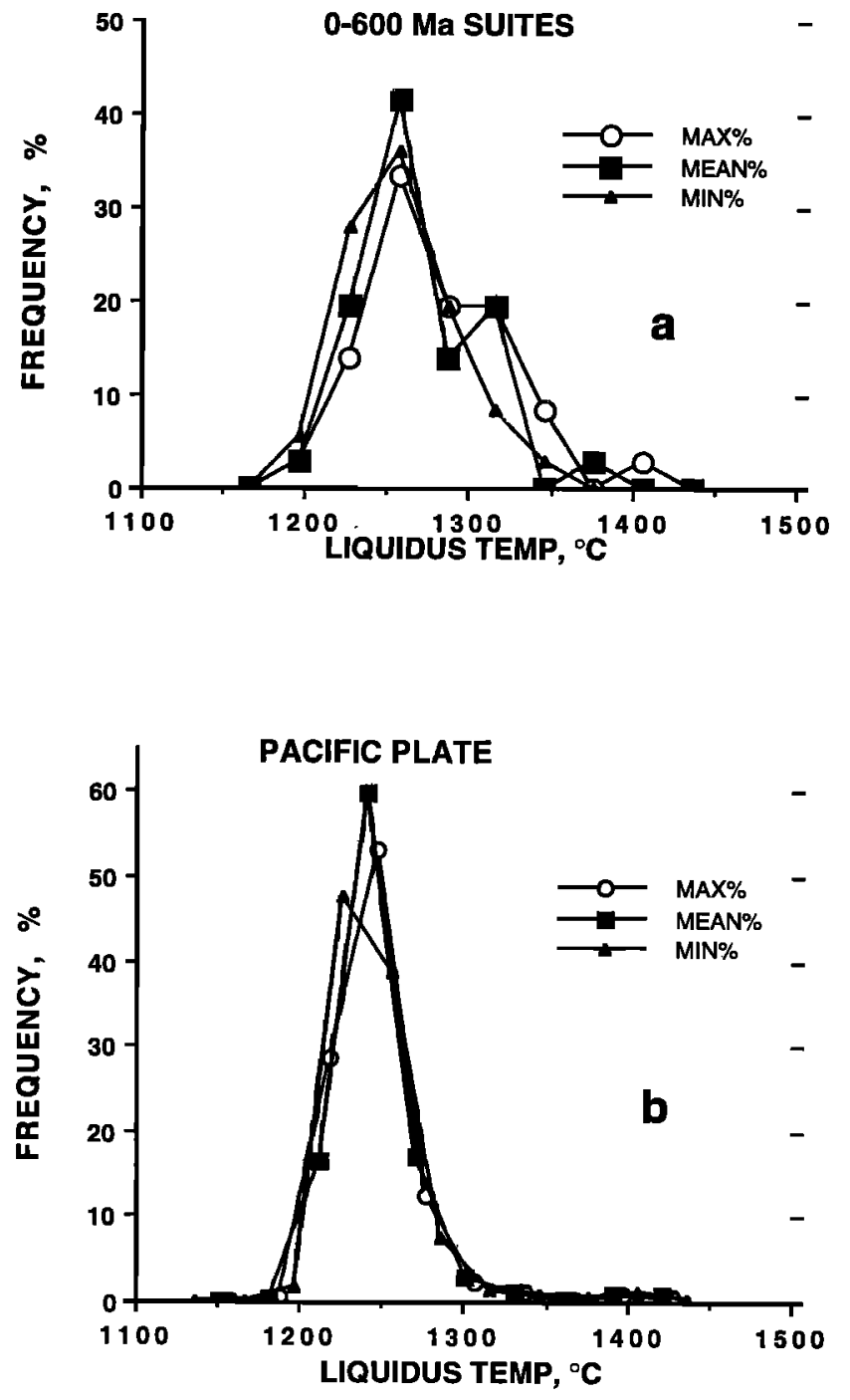

Figure 8. Three percentage areas are shown: MIN, MEAN, and MAX. (a) Distribution of liquidus temperatures derived from the most primitive rock in each of 36 Phanerozoic ophiolite suites compiled for this study. The minimum, mean and maximum histograms were calculated using the error bars for the temperature values in Table 1. (b) Distribution of liquidus temperatures calculated from the residual depth anomalies in the modern Pacific plate. The minimum, mean and maximum histograms are the result of using different bin midpoints for the data.

An additional source of higher temperatures may be the spreading rate distribution of the Phanerozoic ophiolites. It is known that off-ridge hotspots on slow spreading ridges can contaminate and increase the crustal thickness of the on-ridge magmatism. The reason for this is that the slope of the lithosphere-asthenosphere boundary is steep enough on slow spreading ridges to allow hot spot melts to migrate laterally [Rowley et al., 1992]. In contrast, the slope of the lithosphere-asthenosphere boundary on fast spreading ridges is too small to permit lateral melt migration of hot spot magma. Thus oceanic crust created at fast spreading ridges is less influenced by hotspots and will have a residual depth anomaly distribution with a smaller proportion of high temperatures. Although the spreading rate distribution of all of our Phanerozoic ophiolites is not known, some are inferred to have formed at slow spreading ridges [Coleman, 1977, $1984 a, 1984 b]$. We suggest that a temperature distribution derived from crust formed at slow spreading ridges will have a larger high-temperature tail. In contrast, virtually all of the crust formed on the Pacific plate in the last $60 \mathrm{~m}$.y. was formed at ridges which spread at rates that are too high to allow hotspot melts to migrate laterally. Thus part of the relative narrowness of the high-temperature tail of the distribution from the Pacific plate is due to its derivation from crust that formed at high seafloor spreading rates.

Figure 9 compares the shape of the temperature distribution for the Pacific plate with that of the Archean temperatures presented in this paper. We calculated the effects of using temperature data from a broad time interval by adding together three Pacific plate distributions, each offset by $30^{\circ} \mathrm{C}$. The resulting histogram mimics the effects of our estimated $60^{\circ} \mathrm{C}$ change in the liquidus temperature from $2.4 \mathrm{Ga}$ to $3.5 \mathrm{Ga}$. Note that by adding together the three histograms with temperature offsets, we reduce the size of the peak by about half, from $60 \%$
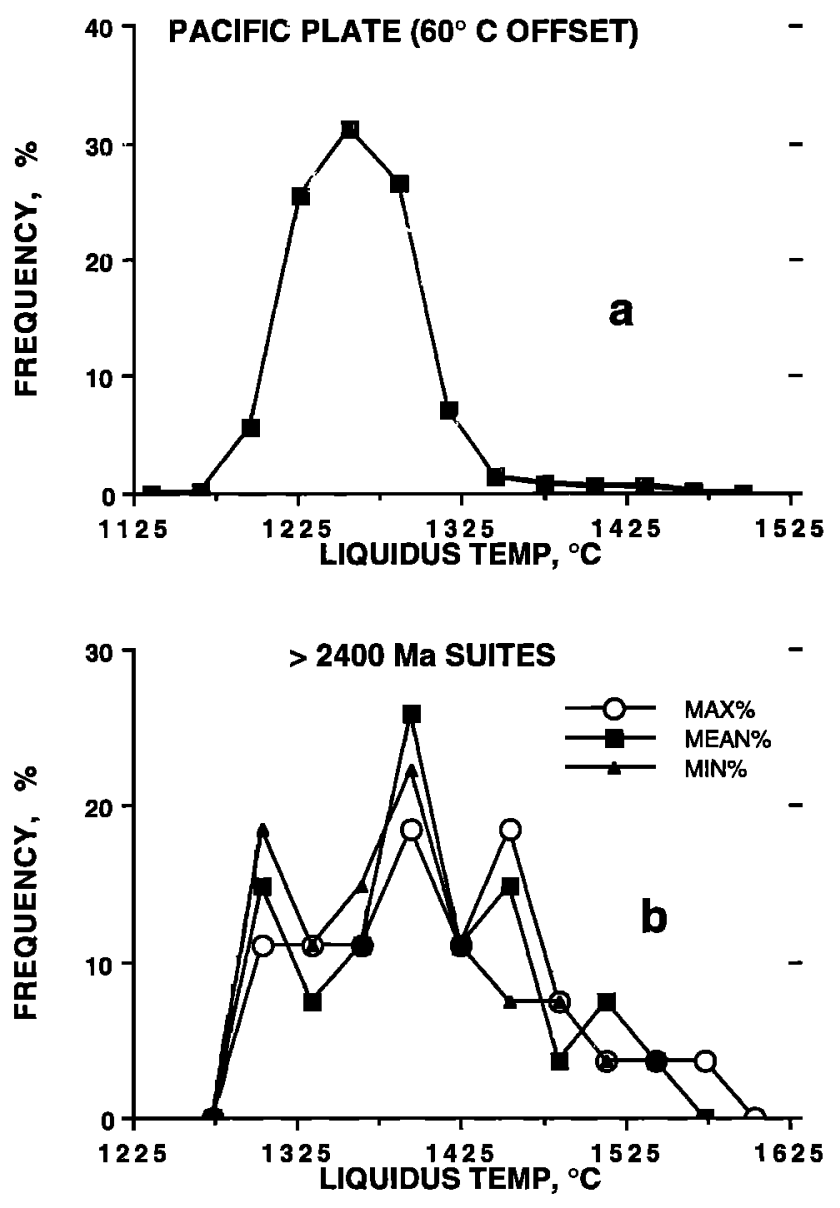

Figure 9. (a) Distribution of liquidus temperatures from the Pacific plate as modeled for the interval 2400-3500 m.y. B.P. During this time interval, mean mantle liquidus temperatures changed by around $60^{\circ} \mathrm{C}$. We modeled the shape of the resulting temperature distribution by adding together three temperature distributions for the Pacific plate to which were added three temperature offsets: $0^{\circ} \mathrm{C}, 30^{\circ} \mathrm{C}$, and $60^{\circ} \mathrm{C}$. (b) Distribution of liquidus temperatures calculated from the most primitive rocks in the Archaean MORBlike suites. Three percentage areas are shown: MIN, MEAN, and MAX. The minimum, mean and maximum histograms were calculated using the error bars for the temperature values in Table 1 . 
to $31 \%$ frequency. We also make the peak broader. For the Archean data, we also calculated minimum and maximum temperature curves from the estimated error in the temperature calculations. Note that only one peak is statistically signficiant: this one peak appears in all three curves. Again, we see the skewed unimodal distribution which was discussed earlier. We also believe that as more data become available from all types of Archean greenstone belts, not only those with komatiites, the cluster of temperatures in the midrange of the distribution will increase in number.

\section{Conclusions}

We have compiled petrological data from 71 greenstone belts and ophiolite suites. We used this data set to calculate the range of mantle temperatures from the early Archean to the present. Our data show that the mean liquidus temperature has declined from roughly $1437 \pm 40^{\circ} \mathrm{C}$ in the middle Archean to roughly $1272 \pm 7^{\circ} \mathrm{C}$ in the Phanerozoic. The highest liquidus temperatures in our data set in each time interval have declined from $1576^{\circ} \mathrm{C}$ in the middle Archean Barberton Greenstone Belt to $1417^{\circ} \mathrm{C}$ in the Phanerozoic Gorgona Island ophiolite. These declines in liquidus temperature are relatively modest. After converting our liquidus temperatures to potential temperature, we find that the mean mantle potential temperature has declined from $1618 \pm 55^{\circ} \mathrm{C}$ in the middle Archean to roughly $1380 \pm 10^{\circ} \mathrm{C}$ in the Phanerozoic. The highest potential temperatures in our data set have declined from $1804^{\circ} \mathrm{C}$ in the middle Archean Barberton Greenstone Belt to $1594^{\circ} \mathrm{C}$ in the Phanerozoic Gorgona Island ophiolite. Consequently, our work does not support the contention of Sleep and Windley [1982], Nisbet and Fowler [1983], and McKenzie [1984] that the Archean mantle was very much hotter than the present-day mantle. Our results are more consistent with those of Jarvis and Campbell [1983] and Campbell and Jarvis [1984].

Because of preservational and sampling biases, our work probably gives an upper bound to the change in mantle temperature since the Archean. The temperature change obtained by using an envelope technique gives a lower bound to the change in mantle temperatures. The amount of change in the potential temperature from the late Archean to the present day ranges from a low of $137 \pm 8^{\circ} \mathrm{C}$ (from temperature ranges) to $187 \pm 42^{\circ} \mathrm{C}$ (from temperature means). The amount of change in the potential temperature from the middle Archean to the present ranges from a low of $177 \pm 14^{\circ} \mathrm{C}$ (from temperature ranges) to a high of $238 \pm 56^{\circ} \mathrm{C}$ (from temperature means). It is reassuring to note that the mean values for the temperature change obtained from both techniques have standard deviations which indicate that the temperature changes are the same within the limits of error.

Our results show that komatiites do not represent "normal" or "average" Archean mantle, as argued by Nisbet and Fowler [1983], but rather fall on the high-temperature tail of a skewed, unimodal Archean temperature distribution. In other words, the temperature distribution of the Archean mantle was not bimodal. Therefore komatiites more probably were derived from Archean hotspots, not from average Archean mantle. These results satisfy the conditions put forth by Kato et al. [1988a, 1988b] with regard to the near-chondritic trace element ratios in the present-day mantle.

The skewed, unimodal shape of our Archean temperature distribution also implies that hotspots produced only a relatively small proportion of magmas in the Archean and hence accounted for only a small percentage of the total oceanic heat loss in the Archean. Consequently, the major method of terrestrial heat loss in the Archean must have been the production, convective hydrothermal cooling, and subduction of normal, ridge-produced oceanic lithosphere, just as it is in the present day. The existence of Archean hotspots also supports the idea of a large temperature discontinuity across the Archean core-mantle boundary [Sleep et al., 1988], because the generation of hotspots is probably the result of plumes formed at that depth.

The results of our comparison of the temperature regimes in the Archean and the Phanerozoic do not support suggestions that there was a sudden change in mantle convection at the Archean-Proterozoic boundary [Campbell and Griffiths, 1992]. Our data are most consistent with a gradual evolution of the temperature regime in the mantle, directly correlated with changes in the rate and amount of radiogenic heat production.

Acknowledgments. We thank William Menke, Mike Bickle, Hazel Chapman, Dave Walker, Geoff Davies, Dave Stevenson, Jeff Weissel, and Sarah Hoffman for helpful comments on the manuscript. We thank the following contracts for partial support of this work: NSF grant EAR8815975 and OCE92-00116. Lamont-Doherty Earth Observatory Contribution \#5184

\section{References}

Aitken, B. G., and L. M. Echeverria, Petrology and geochemistry of komatiites and tholeiites from Gorgona Island, Columbia, Contrib. Mineral. Petrol., 86, 94-105, 1984.

Allart, J. H., The pre-3760 m.y. old supracrustal rocks of the Isua area, Central West Greenland, and the associated occurence of quartzbanded ironstone, in The Early History of the Earth, edited by B. F. Windley, pp. 177-190, John Wiley, New York, 619 pp., 1976.

Anders, E., and N. Grevesse, Abundances of the elements: Meteoritic and solar, Geochim. Cosmochim. Acta, 53, 197-214, 1989.

Anderson, D. L., Theory of the Earth, 366 pp., Blackwell Scientific, Boston, Mass., 1989.

Arndt, N. T., Thick, layered peridotite-gabbro flows in Munro Township, Ontario, Can. J. Earth Sci., 14, 2620-2637, 1977.

Arndt, N. T. and G. A. Jenner, Crustally contaminated komatiites and basalts from Kambalda, Western Australia, Chem. Geol., 56, 229-255, 1986.

Arndt, N. T., and E. G. Nisbet, What is a komatiite?, in Komatiites, edited by N. T. Arndt and E. G. Nisbet, pp. 19-27, Allen and Unwin, Winchester, Mass., 1982.

Arndt, N. T., A. J. Naldrett, and D. R. Pyke, Komatiitic and iron-rich thoeleiitic lavas of Munro Township, northeast Ontario, J. Petrol., 18, 319-369, 1977.

Arndt, N. T., G. E. Brugmann, K. Lehnert, C. Chauvel, and B. W. Chappell, Geochemistry, petrogenesis, and tectonic environment of Circum-Superior belt basalts, in Geochemistry and Mineralization of Proterozoic Volcanic Suites, edited by T.C. Pharaoh, R.D. Beckinsdale, and D. Rickard, Spec. Publ. Geol. Soc. London, 33, pp. 133-145, 1987.

Baragar, W. R. A., and R. F. J. Scoates, Volcanic geochemistry of the northern segments of the Circum-Superior Belt of the Canadian shield, in Geochemistry and Mineralization of Proterozoic Volcanic Suites, edited by T. C. Pharaoh, R. D. Beckinsdale, and D. Rickard, Spec. Publ. Geol. Soc. London, 33, 113-131, 1987.

Barnes, S. J., M. P. Gorton, and A. J. Naldrett, A comparative study of olivine and clinopyroxene spinifex flows from Alexo, Abitibi greenstone belt, Ontario, Canada, Contrib. Mineral. Petrol., 83, 293$308,1983$.

Barnes, S. J., R. E. T. Hill, and M. J. Gole, The Perseverence ophiolite complex, western Australia: the product of a komatiite lava river, $J$. Petrol., 29, 305-331, 1988.

Beccaluva, L., G. B. Piccardo, and G. Serri, Petrology of northern Apenine opholites and comparison with other Tethyan ophiolites, in Ophiolites: Proceedings International Ophiolite Symposium Nicosia Cyprus, 1979, edited by A. Panayiotou, pp. 314-331, Cyprus Geological Survey Department, Nicosia , 1980.

Bernard-Griffiths, J. M., S.N. Carpenter, J.J. Peucat, and B.M. Jahn, Geochemical and isotopic characteristics of blueschist facies rocks 
from the Ile de Groix, Armorican Massif (northwest France), Lithos, $19,235-253,1986$.

Bodinier, J.L., C. Dupuy, J. Dostal, and F. Carme, Geochemistry of ophiolites from the Chamrousse complex (Belledonne Massif, Alps), Contrib. Mineral. Petrol., 78, 379-388, 1981.

Bogatikov, O. A., Early Precambrian Komatiites and High Magnesium Volcanics on the Baltic Shield, (in Russian), 192 pp., Nauka, Leningrad, 1988.

Brouxel, M., and H. LaPierre, Geochenical study of an early Paleozoic island-arc-back-arc basin system, 1, The Trinity ophiolite (northern California), Geol. Soc. Am. Bull., 100, 1111-1119, 1988.

Campbell, I. H., and R. W. Griffiths, The changing nature of mantle hotspots through time: Implications for the chemical evolution of the mantle, J. Geol.92, 497-523, 1992.

Campbell, I. H., and G. T. Jarvis, Mantle convection and early crustal evolution, Precambrian Res., 26, 15-56, 1984.

Campbell, I. H., R. W. Griffiths, and R. I. Hill, Melting in an Archaean mantle plume: Heads it's basalts, tails it's komatiites, Nature, 339, 697699, 1989.

Capedri, S., G. Venturelli, G. Bocchi, J. Dostal, G. Garuti, and A. Rossi, The geochemistry and petrogenesis of an ophiolitic suite from Pindos, Greece, Contrib. Mineral. Petrol., 74, 189-200, 1980.

Casey, J. F., D. L. Elthon, F. X. Siroky, J. A. Karson, and J. Sullivan, Geochemical and geological evidence bearing on the origin of the Bay of Islands and Coastal Complex ophiolites of Westein Newfou.dland, Tectonophysics, 116, 1-40, 1985.

Cattell, A., and N. Arndt, Low- and high-aiumina komatiites from a Late Archaean sequence, Newton Township, Ontario, Contrib. Mineral. Petrol., 97, 218-227, 1987.

Cawood, P. A., A geochemical study of metabasalts from a subduction complex in Eastern Australia, Chem. Geol., 43, 29-47, 1984.

Christie, D. M., I. S. E. Carmichael, and C. H. Langmuir, Oxidation state of mid-ocean ridge basalt glasses, Earth Planet. Sci. Lett. 79, 397-411, 1986.

Coish, R. A., F. S. Fleming, M. Larsen, R. Poyner, and J. Seibert, Early rift history of the Proto-Atlantic ocean: Geochemical evidence from metayolcanic rocks in Vermont, Am. J. Sci., 285, 351-378, 1985.

Coish, R. A., D. A. Perry, C. D. Anderson, and D. Bailey, Metavolcanic rocks from the Stowe formation, Vermont: Remnants of ridge and intraplate volcanism in the Iapetus Ocean, Am. J. Sci., 286, 1-28, 1986.

Coleman, R. G., Ophiolites: Ancient Oceanic Lithosphere?, SpringerVerlag, New York, 1977.

Coleman, R. G., Ophiolites and the tectonic evolution of the Arabian Peninsula, in Ophiolites and Oceanic Lithosphere, edited by I. G. Gass, S. J. Lippard, and A. W. Shelton, pp. 359-366, Blackwell Scientific, Boston, Mass., 1984a.

Coleman, R. G., The diversity of ophiolites, Geol. Mijnbouw, 63, 141-150, $1984 \mathrm{~b}$.

Condie, K. C., M. J. Viljoen, and E. J. D. Kable, Effects of alteration on element distributions of Archean tholeiites from the Barberton greenstone belt, South Africa, Contrib. Mineral. Petrol., 64, 75-89, 1977.

Crawford, A. J., and R. R. Keays, Petrogenesis of Victorian Cambrian tholeiites and implications for the origin of associated boninites, $J$. Petrol., 28, 1075-1109, 1987.

Davis, T. E., M. R. Johnston, P. C. Rankin, and R. J. Still, The Dun mountain ophiolite belt in East Nelson, New Zealand, in Ophiolites: Proceedings International Ophiolite Symposium Cyprus, 1979, edited by A. Panayiotou, pp. 480-496, Cyprus Geological Survey Department, Nicosia, 1980.

Defant, A., Physical Oceanography, vol. 1, 729 pp., Pergamon, New York, 1961 .

Desmons, J., and L. Beccaluva, Mid-ocean ndge and island-arc affinities in ophiolites from Iran: paleogeographic implications, Chem. Geol., 39, $39-63,1983$.

Dobrzhinestakaya, L. F., Petrochemistry and geochemistry of the volcanic and plutonic basite-hyperbasite rocks in the early Proterozoic BaykalVitim Greenstone Belt, Geokhimiya 7, 15-28, 1986.

Drury, S. A., Geochemistry of Archaean metavolcanic rocks from the Holenarsipur and Shigegudda volcano-sedimentary belts of Karnataka, South India, Precambrian Res., 19, 119-139, 1982.

Dungan, M. A., J. A. Vance, and D. P. Blanchard, Geochemistry of the Shuksan greenschists and blueschists, North Cascades, Washington: Variably fractionated and altered metabasalts of oceanic affinity, Contrib. Mineral. Petrol., 82, 131-146, 1983.

Dunning, G. R., and T. E. Krogh, Geochronology of ophiolites of the Newfoundland Appalachians,Can. J. Earth Sci., 22, 1659-1670, 1985.

Dunning, G. R., and $\mathrm{R}$. B. Pedersen, U/Pb ages of ophiolites and arcrelated plutons of the Norwegian Caledonides: Implications for the development of Iapetus, Contrib. Mineral. Petrol., 98, 13-23, 1988.

Dymek, R. F., S. C. Brothers and C. M. Schiffries, Petrogenesis of ultramafic metamorphic rocks from the $3800 \mathrm{Ma}$ Isua Supercrustal Belt, West Greenland, J. Petrol., 29, 1353-1397, 1988.

Echeverria, L. M., Tertiary and Mesozoic komatites from Gorgona island, Colombia: Field relations and geochemistry, Contrib. Mineral. Petrol., 73, 253-266, 1980.
Elthon, D. and W. I. Ridley, The petrology of the Tortuga ophiolite complex, southern Chile, in Ophiolites: Proceedings International Ophiolite Symposium Cyprus, 1979, edited by A. Panayiotou, pp. 507513, Cyprus Geological Survey Department, Nicosia, 1980.

Elueze, A. A., Petrochemical and petrogenetic characteristics of Precambrian amphibolites of the Alawa district, Northwest Nigeria, Chem. Geol., 45, 29-41, 1985.

Flower, M. F. J., and H. M. Levine, Petrogenesis of a tholeiite-boninite sequence from Ayios Mamas, Troodos ophiolite: Evidence for splitting of a volcanic arc?, Contrib. Mineral. Petrol., 97, 509-524, 1987.

Francis, D., and A. J. Hynes, Komatiite-derived tholeiites in the Proterozoic of New Quebec, Earth Planet. Sci. Lett., 44, 473-481, 1979.

Francis, D.M., A.J. Hynes, J.N. Ludden, and J. Bedard, Crystal fractionation and partial melting in the petrogenesis of a Proterozoic high-MgO volcanic suite, Ungava, Quebec, Contrib. Mineral. Petrol., $78,27-36,1981$.

Friend, C.R.L. R.P. Hall, and D.J. Hughes, The geochemistry of the Malene (Mid-Archaean) ultramafic-mafic amphibolite suite, southern west Greenland, Archean Geology, 2nd Int. Symp., edited by J. E. Glover and D.I. Groves, Spec. Publ. Geol. Soc. Aust., 7, 515 pp., 1981.

Furnes, H., D. Roberts, B. Sturt, B. A. Thon, and G.H. Gale, Ophiolite fragments in the Scandinavian Caledonides, in Ophiolites: Proceedings International Ophiolite Symposium Cyprus, 1979, edited by A Panayiotou, pp. 582-599, Cyprus Geological Survey Department, Nicosia, 1980.

Furnes, H., A. Thon, J. Nordas, and L. B. Garmann, Geochemistry of Caledonian metabasalts from some Norwegian ophiolite fragments, Contrib. Mineral. Petrol., 79, 295-307, 1982.

Furnes, H., R. B. Pederson, and C. J. Stillman, The Leka ophiolite complex, central Norwegian Caledonides: Field characteristics and geotectonic significance, J. Geol. Soc. London, 145, 401-412, 1988.

Gill, J. B., Sr-Pb-Nd isotopic evidence that both MORB and OIB sources contribute to oceanic island arc magmas in Fiji, Earth Planet. Sci. Lett., $68,443-458,1984$.

Girardeau, J., J. C. C. Mercier, and W. Xibin, Petrology of the mafic rocks of the Xigaze ophiolite, Tibet, Contrib. Mineral. Petrol., 90, 309$321,1985$.

Goldich, S. S., C. E. Hedge,T. W. Stern, J. L. Wooden, J. B. Bodkin, and R. M. North, Archean rocks of the Granite Falls area, southwestern Minnesota, pp. 19-43, Spec. Pap. Geol. Soc. Am., 182 pp., 1980.

Green, J. C., and K. J. Schulz, Iron-rich basaltic komatiites in the early Precambrian Vermillion district, Minnesota, Can. J. Earth Sci., 14, 2181-2192, 1977.

Gruau, G., B. M. Jahn, A. Y. Glikson, R. Davy, A. H. Hickman, and C. Chauvel, Age of the Archean Talga-Talga subgroup, Pilbara block, Western Australia and early evolution of the mantle: New Sm-Nd isotopic evidence, Earth Planet. Sci. Lett., 85, 105-116, 1987.

Halden, N. M., Existence of a marginal basin within the Circum-Superior Belt: Geochemical evidence from the Churchill-Superior boundary in Manitoba, Canada, Precambrian Res., 49, 167-183, 1991.

Hall, R., Disrupted Tethyan ophiolites, in Ophiolites: Proceedings International Ophiolite Symposium Cyprus, 1979, edited by A. Panayiotou, pp. 287-291, Cyprus Geological Survey Department, Nicosia, 1980.

Hall, R. P. The tholeiitic and komatiitic affinities of the Malene metavolcanic amphibolites from Ivisartoq, southwestern Greenland, pp. 1-20, Rapp. 97, Groenl. Geol. Unders., 1980a.

Hallberg, J. A., D. N. Carter, and K.N. West, Archaean volcanism and sedimentation near Meekatharra, Western Australia, Precambrian Res., 3, 577-595, 1976.

Hanruo, W. and D. Wanming, Basic geological features of the Yarlung Zangbo ophiolite belt, Xizang, China, in Ophiolites: Proceedings International Ophiolite Symposium Cyprus, 1979, edited by A. Panayiotou, pp. 462-472, Cyprus Geological Survey Department, Nicosia, 1980.

Hanski, E., Komatiitic and tholeiitic metavolcanics of the Siivikkovaara area in the Archean Kuhmo greenstone belt, Eastern Finland, Suom. Geol. Seura Bull., 52, 67-100, 1980.

Hawkins, J., Petrology of back-arc basins and island arcs: Their possible role in the orignn of ophiolites, in Ophiolites: Proceedings International Ophiolite Symposium Cyprus, 1979, edited by A. Panayıotou, pp. 244254, Cyprus Geological Survey Department, Nicosia, 1980

Heaman, L. M., N. Machado, T. E. Krogh, and W. Weber, Precise U-Pb zircon ages for the Molson dyke swarm and the Fox River sill: Constraints for Early Proterozoic crustal evolution in northeastern Manitoba, Canada, Contrib. Mineral. Petrol., 94, 82-89, 1986.

Hoffman, P. F., and G. Ranalli, Archean oceanic flake tectonics, Geophys. Res. Lett., 15, 1077-1080, 1988.

Hoffman, S. E., Alteration minerology and geochemustry of the Archean Onverwacht group, Barberton Mountain Land, South Africa, M.S. thesis, 386 pp., Oregon State Univ., Corvallis, 1984.

Hussain, S. M., and S. M. Naqvi, Geological, geophysical, and geochemical studies over the Holenarsipur schist belt, in Precambrian of South India, edited by S. M. Naqvi and J. J. W. Rogers, Mem. Geol. Surv. India, 4, 73-95, 1983. 
Hussain, S. M., S. M. Naqvi, and T. G. Rao, Geochemistry and significance of mafic-ultramafic rocks from the southern part of the Holenarsipur schist belt, Karnataka, J. Geol. Soc. India, 23, 19-31, 1982.

Jahn, B. M., and W. G. Ernst, Late Archean Sm-Nd isochron age for mafic-ultramafic supracrustal amphibolites from the northeastern SinoKorean craton, China, Precambrian Res., 46, 295-306, 1990.

Jahn, B. M., Mid-ocean ridge ophiolite or marginal basin origin of the East Taiwan ophiolite: chemical and isotopic evidence, Contrib. Mineral. Petrol., 92, 194-206, 1986.

Jahn, B. M., B. Auvray, S. Blais, R. Capdevila, J. Cornichet, F. Vidal, and J. Hameurt, Trace element geochemistry and petrogenesis of Finnish greenstone belts, J. Petrol., 21, 201-244, 1980.

Jarvis, G., and I. H. Campbell, Archean komatiites and geotherms: Solution to an apparent contradiction, Geophys. Res. Lett., 10, 11331136,1983

Kato, T, A. E. Ringwood, and T. Irifune, Experimental determination of element partitioning between silicate perovskites, garnets, and liquids: Constraints on early differentiation of the mantle, Earth Planet. Sci. Leth. 89, 123-145, 1988a.

Kato, T., A. E. Ringwood, and T. Irifune, Constraints on element partition coefficients between $\mathrm{MgSiO}_{3}$ perovskite and liquid determined by direct measurements, Earth Planet. Sci. Lett., 90, 65-68, $1988 \mathrm{~b}$.

Klein, E. M., and C. H. Langmuir, Global correlations of ocean ridge basalt chemistry with axial depth and crustal thickness, J. Geophys. Res., 92, 8089-8115, 1987.

Konnikov, E. G., On the problem of ophiolites of the Baikal-Muya Belt, Sov. Geol. Geophys., Engl. Transl., 32(3), 104-113, 1991.

Kontinen, A., An early Proterozoic ophiolite - The Jormua maficultramafic complex, northeastern Finland, Precambrian Res., 35, 313$341,1987$.

Kroenke, L. W., W. H. Berger, T. R. Janecek et al., Introduction, Proceedings of the Ocean Drilling Program, Initial Reports, 130, pp 5 9, College Station, Texas, (Ocean Drilling Program), 1991.

Kroner, A., and W. Todt, Single zircon dating constraining the maximum age of the Barberton greenstone belt, southern Africa, J. Geophys. Res., 93, 15,329-15,339, 1988.

Kulikova, V. V., V.S. Kulikov, and A. A. Cherepanov, Tokshinsky structure, in Volcanism of the Archean Greenstone Belts of Karelia (in Russian), edited by V. A. Sokolov, pp. 56-61, Nauka, Leningrad, $1981 a$.

Kulikov, V. S, V. V. Kulikova, and V. N. Furman, Kamennozero structure, in Volcanism of the Archean Greenstone Belts of Karelia (in Russian), edited by V. A. Sokolov, pp. 41-50, Nauka, Leningrad, $1981 b$.

Kulikova, V. V., and V. S. Kulikov, Schilos structure, in Volcanism of the Archean Greenstone Belts of Karelia (in Russian), edited by V. A Sokolov, pp. 29-37, Nauka, Leningrad, 1981.

Langmuir, C. H., E. M. Klein, and T. Plank, Petrological constraints on mid-ocean ridge basalts: constraints on melt generation beneath ocean ridges, Mantle Flow and Melt Generation at Mid-Ocean Ridges, Geophys. Mono. 71, 361pp., 183-280, 1992.

Leeman, W. P., D. R. Smith, W. Hildreth, Z. Palacz, and N. Rogers, Compositional diversity of late Cenozoic basalts in a transect across the southern Washington Cascades: Implications for subduction zone magmatism, J. Geophys. Res., 95, 19,561-19,582, 1990.

Lippard, S. J., A. W. Shelton, and I. G. Gass, The Ophiolite of Northem Oman, Mem.11, Geol. Soc. of London, 1-178 Pp., 1986.

Lobach-Zuchenko, S. B., N.A. Arestova, and I. N. Krylov, Palaja Lamba greenstone belt, in Geology and Petrology of Archean GraniteGreenstone Complexes in Karelia (in Russian), edited by K. O. Kratz, pp. 8-57, Nauka, Leningrad, 1978.

Longhi, J., D. Walker, and J. F. Hays, The distribution of $\mathrm{Fe}$ and $\mathrm{Mg}$ between olivine and lunar basaltic liquids, Geochim. Cosmochim. Acta, 42, 1545-1558, 1978

Ludden, J., C. Hubert, and C. Gariepy, The tectonic evolution of the Abitibi greenstone belt of Canada, Geol. Mag., 123, 153-166, 1986.

Mahoney, J. J.,et al. Geochemistry and age of the Ontong Java Plateau, in The Mesozoic Pacific: Geology, Tectonics and Volcanism, Geophys. Mono. 77, edited by M. S. Pringle, W. W. Sager and S. Stein, pp. 233261, 1993.

McGregor, V. R., and B. Mason, Petrogenesis and geochemistry of metabasaltic and metasedimentary enclaves in the Amitsoq gneisses, West Greenland, Am. Mineral., 62, 887-904, 1977.

McKenzie, D. P., The generation and compaction of partially molten rock, J. Petrol., 25, 713-765, 1984

McKenzie, D. P., and M.J. Bickle, The volume and composition of melt generated by extension of the lithosphere, J. Petrol., 29, 625-679, 1988.

McNutt, M. K., and A. V. Judge, The superswell and mantle dynamics beneath the South Pacific, Science, 248, 969-975, 1990.

Michard-Vitrac, A., J. Lancelot, and C. J. Allegre, U-Pb ages on single zircons from the early Precambrian rocks of West Greenland and the Minnesora River valley, Earth Planet. Sci. Lett., 35, 449-453, 1977.

Miyake, Y., MORB-like tholeiites formed within the Miocene forearc basin, Southwest Japan, Lithos, 18, 23-34, 1985.

Montigny, R., H. Bougalt, Y. Bottinga, and C. J. Allegre, Trace element geochemistry and genesis of the Pindos ophiolite suite, Geochim. Cosmochim. Acta, 37, 2135-2147, 1973.

Moore, J. M., Jr., Orogenic volcanism in the Proterozoic of Canada, Spec. Pap. Geol. Assoc. Can. in Volcanic Regimes in Canada, edited by W. R. A. Baragar, L. C. Coleman, and J. M. Hall, 16, 127-148, 1977.

Mottana, A., R. Bocchio, G. Liborio, L. Morten, and W. V. Maresch, The eclogite-bearing metabasaltic sequence of Isla Margarita, Venezuela: a geochemical study, Chemical Geology, 50, 351-368, 1985.

Mutanen, T., Komatiites and komatiite provinces in Finland, Geologi, 28 49-56, 1976 .

Naldrett, A. J., and A. R. Turner, The geology and petrogenesis of a greenstone belt and related nickel sulfide mineralization at Yakabindie, Western Australia, Precambrian Res., 5, 43-103, 1977.

Nesbitt, R. W., I. W. Walker, and D.F. Blight, Geochemistry of Archean metabasaltic lavas, Diemals, Western Australia, in Archean Geology, edited by J. E. Grover and D. I. Groves, Report Geol. Surv. Westerm Aust., 12, 15-26, 1984.

Nisbet, E. G., and C. M. R. Fowler, Model for Archean plate tectonics, Geology, i1, 376-379, 1983.

Nisbet, E. G., and M. J. Cheadle, Constraints on Archean magmatism from fresh komatiites, paper presented at International Geological Congress, Kyoto, Japan, August 24-Sept. 3, 1992.

Nisbet, E. G., M. J. Bickle, and A. Martin, The mafic and ultramafic lavas of the Belingwe greenstone belt, Rhodesia, J. Petrol., 18, 521-566, 1977.

Nisbet, E. G., et al., Uniquely fresh $2.7 \mathrm{Ga}$ komatiites from the Belingwe greenstone belt, Zimbabwe, Geology, 15, 1147-1150, 1987.

Nutman, A. P., The early Archaean to Proterozoic history of the Isukasia area, southern West Greenland, Bull.Groen.. Geol. Unders. 154, 1-71, 1986.

O'Hara, M. J., Zoned ultrabasic and basic gneiss masses in the early Lewisian metamorphic complex at Scourie, Sutherland, J. Petrol., 2, 248-276, 1961

Ottonello, G., J. L. Joron, and G. B. Piccardo, Rare earth and 3D transition element geochemistry of peridotitic rocks, II, Ligurian peridotites and associated basalts, J. Petrol., 25, 373-393, 1984.

Paktunc, D. A., Petrogenesis of ultramafic and mafic rocks of the Thompson Nickel Belt, Manitoba, Contrib. Mineral. Petrol., 88, 348$353,1984$.

Pallister, J. S., J. R. Budahan, and B. L. Murchey, Pillow basalts of the Angayucham terrane: Oceanic plateau and island crust accreted to the Brooks range, J. Geophys. Res., 94, 15,901-15,923, 1989.

Parrot, J. F., Assemblage ophiolitique du Baer-Bassit et termes effusifs du volcano-sedimentaire, Trav. Doc. ORSTOM, 72, 292 pp., 1977.

Parsons, B. A. Causes and consequences of the relation between area and age of the ocean floor, J. Geophys. Res., 87, 289-302, 1982.

Parsons, B., and J. G. Sclater, An analysis of the variation of ocean floor bathymetry and heat flow with age, J. Geophys. Res., 82, 803-827, 1977.

Pearce, J. A., and J. R. Cann, Tectonic setting of basic volcanic rocks determined using trace element analyses, Earth Planet. Sci. Lett., 19, 290-300, 1973

Pearce, J. A., and M. J. Norry, Petrogenetic implications of Ti, Zr, Y, and $\mathrm{Nb}$ variations in volcanic rocks, Contrib. Mineral. Petrol., 69, 33-47, 1979.

Pearce, J. A., S. J. Lippard, and S. Roberts, Characteristics and tectonic significance of supra-subduction zone ophiolites, in Marginal Basin Geology, edited by B. P. Kokelaar, and M. F. Howells, Spec. Publ. Geol. Soc. London, 16, 77-94, 1984.

Peredery, W. V., Relationship of ultramafic amphibolites to metavolcanic rocks and serpentinites in the Thompson Belt, Manitoba, Can. Mineral., $17,187-200,1979$.

Prestvik, T. The Caledonian ophiolite complex of Leka, north central Norway, in Ophiolites: Proceedings International Ophiolite Symposium Cyprus, 1979, edited by A. Panayiotou, Cyprus Geological Survey Department, Nicosia, pp. 555-556, 1980.

Rajamani, V., K. Shivkumar, G. N. Hanson, and S. B. Shirey Geochemistry and petrogenesis of amphibolites, Kolar schist belt, South India: Evidence for komatiitic magma derived by low percentages of melting of the mantle, J. Petrol., 26, 92-123, 1985.

Rautenschlein, M., G. A. Jenner, J. Hertogen, A. W. Hofmann, R. Kerrich, H. U. Schminke, and W. M. White, Isotopic and trace element composition of volcanic glasses from the Akaki canyon, Cyprus: Implications for the origin of the Troodos ophiolite, Earth Planet. Sci. Lett., 75, 369-383, 1985.

Ray, K. K., S. Sengupta, and H. J. Van den Hul, Chemical characters of volcanic rocks from Andaman ophiolite, India, J. Geol. Soc. London., 145, 393-400, 1988.

Richardson, S. H., J. J. Gurney, A. J. Erlank, and J. W. Harris, Origin of old diamonds in enriched mantle, Nature, 310, 198-202, 1984.

Rivalenti, G. V., A. V. Girardi, M. Coltorti, C. T. Correia and M Mazzucchelli, Geochemical models for the petrogenesis of komatiites from the Hidrolina Greenstone Belt, Central Goias, Brazil, J. Petrol., 30, 175-197, 1989.

Roeder, P. L., and R. F. Emslie, Olivine-liquid equilibrium, Contrib. Mineral. Petrol., 29, 275-289, 1970. 
Rogers, G., and A. D. Saunders, Magnesian andesites from Mexico, Chile and the Aleutian Islands: Implications for magmatism associated with ridge-trench collision, in Boninites, edited by A.J. Crawford, Unwin Hyman, pp. 416-445, London, 1989.

Rowley, C., C. W. Gable, and C. Kincaid, Dynamical interaction between upper mantle plumes and a spreading ridge: Three-dimensional experiments (abstract), Eos Trans. AGU, 73, 582, 1992.

Rybakov, S. I., and A. I. Svetova, Koikary-Korbozero structure, in Volcanism of the Archean Greenstone Belts of Karelia (in Russian), edited by V.A. Sokolov, pp. 17-21, Nauka, Leningrad, 1981a.

Rybakov, S. I., and A. I. Svetova, Paloselvginsky structure, in Volcanism of the Archean Greenstone Belts of Karelia (in Russian), edited by $\mathrm{V}$. A. Sokolov, pp. 22-26, Nauka, Leningrad, $1981 \mathrm{~b}$.

Schubert, G., and D. Sandwell, Crustal volumes of continents and of oceanic and continental submarine plateaus, Earth Planet. Sci. Lett., 92, 234-246, 1989.

Schulz, K. J., The petrology and geochemistry of Archean volcanics, western Vermillion district, northwestern Minnesota, Ph.D. thesis, 366 pp., Univ. of Minn., 1977.

Schulz, K. J., Magnesian basalts from the Archaean terrains of Minnesota, in Komatiites, edited by N.T. Arndt and E.G. Nisbet, pp. 171-186, Allen and Unwin, Winchester, Mass., 1982.

Scott, D. J., M. R. St-Onge, S. B. Lucas and H. Helmstaedt, The $1998 \mathrm{Ma}$ Purtuniq ophiolite: Imbricated and metamorphosed oceanic crust in the Cape Smith thrust belt, northern Quebec, Geology, 16, 144-151, 1988.

Sills, J. D., D. Savage, J. V. Watson, and B. F. Windley, Layered ultramafic-gabbro bodies in the Lewisian of northwest Scotland: Geochemistry and petrogenesis, Earth Planet. Sci. Lett., 58, 345-360, 1982.

Sims, P. K., and G. B. Morey, Geology of Minnesota: A Centennial Volume, St. Paul, Minn., Minnesota Geol. Survey, 632 pp., 1972.

Skjerlie, K. P., H. Furnes, and R. J. Johansen, Magmatic development and tectonomagmatic model of the Solund-Stavfjord ophiolite complex, West Norwegian Caledonides, Lithos, 23, 137-151, 1989.

Sleep, N. H., and B. F. Windley, Archean plate tectonics: Constraints and inferences, J. Geol., 90, 1129-1234, 1982.

Sleep, N. H., M. A. Richards, and B. H. Hager, Onset of mantle plumes in the presence of preexistung convection, J. Geophys. Res., 93, 7672 $7689,1988$.

Smewing, J. D., and P. J. Potts, Rare-earth abundances in basalts and metabasalts from the Troodos Massif, Cyprus, Contrib. Mineral. Petrol., $57,245-258,1976$

Smuth, H. S., J. R. O'Nell, and A. J. Erlank, Oxygen isotope compositions of minerals and rocks and chemical alteration patterns in pillow lavas from the Barberton greenstone belt, South Africa, in Archean Geochemistry, edited by A. Kroner et al., pp. 115-137, SpringerVerlag, New York, 1984.

Smith, W. H. F., Marine geophysical studies of seamounts in the Pacific Ocean, Ph.D. thesis, Columbia Univ., New York, 1990.

Smith, W. H. F., On the accuracy of digital bathymetric data, J. Geophys. Res., 98, 9591-9603, 1993 .

Smith, W. H. F., and J. P. Morgan, A dynamic origin for asymmetric subsidence and geoid anomalies in the South Atlantic Ocean? (abstract), Eos Trans. AGU, 73, 582, 1992.

Sokolov, V. A., Volcanism of the Archaean Greenstone Belts of Karelia (in Russian), 152 pp., Nauka, Leningrad, 1981

Spadea, P., M. Delaloye, A. Espinosa, A. Orrego, and J. J. Wagner, Ophiolite complex from La Tetilla, Southwestern Columbia, South America, J. Geol., 95, 377-395, 1987.

Stein, C. A., and D. H. Abbott, Heat flow constraints upon the South Pacific Superswell, J. Geophys. Res., 96, 16,083-16,100, 1991.

Stern, C., Geochemistry of Chilean ophiolites: Evidence for compositional evolution of the mantle source of back-arc basin basalts, $J$. Geophys. Res., 85, 955-966, 1980.

Sturt, B. A., D. Roberts, and H. Furnes, A conspectus of Scandinavian Caledonian ophiolites, in Ophiolites and Oceanic Lithosphere, edited by I. G. Gass, S. J. Lippard, and A. W. Shelton, pp. 381-391, Blackwell Scientific, Boston, Mass., 1984.
Suen, C. J., F. A. Frey, and J. Malpas, Bay of Islands ophiolite suite Newfoundland: Petrologic and geochemical characteristics with emphasis on rare earth element geochemistry, Earth Planet. Sci. Lett., 45, 337-348, 1979 .

Sun, S. S., and R. W. Nesbitt, Petrogenesis of Archean ultrabasic and basic volcanics: Evidence from rare earth elements, Contrib. Mineral. Petrol., 65, 301-325, 1978.

Suppe, J., J. G. Liou, and W. G. Ernst, Paleogeographic origins of the Miocene East Taiwan ophiolite, Am. J. Sci., 281, 228-246, 1981.

Tegyey, M., and V. Johan, Une sequence komatiitique dans le Proterozoique inferieur de Guinee (Afrique de l'Ouest): Caracteres petrographiques, mineralogiques et geochimiques, Petrologie, C.R. Acad. Sci. Paris, 308, 193-200, 1989.

Tremblay, A., R. Hebert, and M. Bergeron, Le complex d'Ascot des Appalaches du sud du Quebec: Petrologie et geochemie, Can. J. Earth Sci., 26, 2407-2420, 1989.

Ulmer, P., The dependence of the $\mathrm{Fe} 2+-\mathrm{Mg}$ cation partitioning between olivine and basaltic liquid on pressure, temperature, and composition, Contrib. Mineral. Petrol., 101, 261-273, 1989.

Venkataramana, P., Chemical remnants of the Archaean protocrust in the Sargur schist belt of Karnataka craton, India, Precambrian Res., 19, $51-74,1982$.

Vidal, P., S. Blais, B. M. Jahn, R. Capdevila, and G. R. Tilton, U-Pb and $\mathrm{Rb}$-Sr systematics of the Suomussalmi Archean greenstone belt (Eastern Finland), Geochim. Cosmochim. Acta 44, 2033-2044, 1980.

Viljoen, M. J., and R. P. Viljoen, Evidence for the existence of a mobile extrusive peridotitic magma from the Komati formation of the Onverwacht Group, in Upper Mantle Project pp. 88-113, Geol. Soc. S. Afr., Spec. Publ. No. 2, 1969.

Volpe, A. M., and J. D. Macdougall, Geochemistry and isotopic characteristics of mafic (Phalud Ophiolite) and related rocks in the Delhi supergroup, Rajasthan, India: Implications for rifting in the Proterozoic, Precambrian Res., 48, 167-191, 1990.

Walker, R. J., S. B. Shirey, and O. Stecher, Comparative Re-Os, Sm-Nd, and $\mathrm{Rb}$-Sr isotope and trace element systematics for Archean komatiite flows from Munro Township, Abitibi Belt, Ontario, Earth Planet. Sci. Lett., 87, 1-12, 1988.

Wasserburg, G. J., G. J. MacDonald, F. Hoyle, and W. A. Fowler, Relative contributions of uranium, thorium and potassium to heat production in the Earth, Science, 143, p. 465, 1964.

White, R. S., D. MacKenzie, and R. K. O'Nions, Oceanic crustal thickness from seismic measurements and rare earth element inversions, $J$. Geophys. Res., 97, 19,683-19,715, 1992.

Wooden, J. L., S. S. Golduch, and N. H. Suhr, Origin of the Morton Gneiss, southwestern Minnesota, 2, Geochemistry, Spec. Pap. Geol. Soc. Am. $182,57-75,1980$.

Zhai, M. G., R. Y. Yang, W. Lu, and J. Zhou, Geochemistry and evolution of the Qingyuan Archaean granite-greenstone terrain, NE China, Precambrian Res., 27, 37-62, 1985.

Zhai, M. G., B. F. Windley, and J. D. Sills, Archaean gneisses, amphibolites, and banded iron formations from the Anshan area of Liaoning Province, NE China: Their geochemistry, metamorphism and petrogenesis, Precambrain Res., 46, 195-216, 1990.

D. Abbott, L. Burgess, and J. Longhi, Lamont-Doherty Earth Observatory, Rm 103A - Oceanography Building, Palisades, NY 10964

W.H.F. Smith, NOAA Geosciences Lab., N/OES-12, Building SSMC-12, Stat 8423, 1305 East West Highway, Silver Springs, MD 20910

(Received February 15, 1993; revised October 18, 1993; accepted January 13, 1994.) 